FACULTY OF ECONOMICS AND APPLIED ECONOMIC SCIENCES

CENTER FOR ECONOMIC STUDIES

ENERGY, TRANSPORT \& ENVIRONMENT

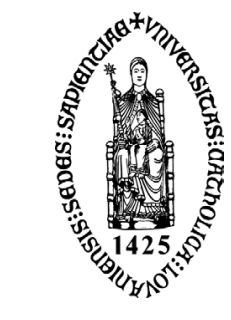

KATHOLIEKE UNIVERSITEIT

LEUVEN

WORKING PAPER SERIES

$n^{\circ}$ 2003-15

\title{
The opening of the European electricity market and environmental policy: does the degree of competition matter?
}

\section{A. Bigano (Fondazione Eni-Enrico Mattei (Venice Italy)) \\ S. Proost (K.U.Leuven)}

December 2003

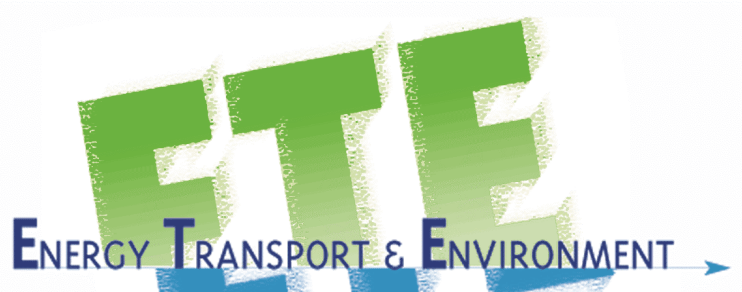

secretariat:

Isabelle Benoit

KULeuven-CES

Naamsestraat 69, B-3000 Leuven (Belgium)

tel: $\quad+32(0) 1632.66 .33$

fax: $\quad+32(0) 1632.69 .10$

e-mail: Isabelle.Benoit@econ.kuleuven.ac.be http://www.kuleuven.be/ete 


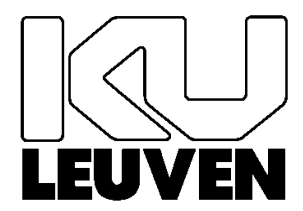

KATHOLIEKE

UNIVERSITEIT

LEUVEN

\title{
The opening of the European electricity market and environmental policy: does the degree of competition matter? ${ }^{1}$
}

\author{
Andrea Bigano ${ }^{2}$ and Stef Proost ${ }^{3}$
}

\begin{abstract}
This paper studies the relevance of strategic trade effects in the environmental policy for the European electricity sector. The production, investment and trade of electricity are modelled for four European countries. Three market regimes are distinguished: perfect competition, price regulation and Cournot competition. The model is used to examine the effect of the degree of competition on the state of the environment and to study the strategic trade effects of unilateral environmental policies.
\end{abstract}

Keywords: Electricity, Trade and the Environment,

JEL-classification: L94, F18, D43.

Corresponding Address: Andrea Bigano 1 This research was funded by a research grant of the Katholieke Universiteit Leuven (OT), We acknowledge
useful comments from A. Ulph, E. Schokkaert, F.Abraham, F. Spinnewijn, C. Crombez, L. Franckx, and from
seminar participants at The $2^{\text {nd }}$ World Congress of Environmental and Resource Economists (Monterrey,
California, USA,) at the Twelfth EAERE Conference (Bilbao,Spain), RFF (Washington DC, USA), SPEED
(Oldenb urg, Germany).
2 Fondazione Eni-Enrico Mattei (Venice Italy), The Abdus Salam Center for Theoretical Physics, (Trieste, Italy) and
the Center for Economic Studies, Katholieke Universiteit Leuven (Leuven, Belgium).

${ }^{3}$ Center for Economic Studies, Katholieke Universiteit Leuven (Leuven, Belgium).

\section{ENERGY, TRANSPORT AND ENVIRONMENT}

CENTER FOR ECONOMIC STUDIES

Naamsestraat 69 B-3000 LEUVEN

BELGIUM 
Fondazione Eni Enrico Mattei

Campo S.Maria Formosa

Castello 4778-5252 / 30122 Venezia

Italy

FAX

$+39-41-2711461$

/e-mail:Andrea.Bigano@feem.it 


\section{The Opening of the European Electricity Market and Environmental Policy: Does the Degree of Competition Matter?}

\section{INTRODUCTION}

Virtually all generation technologies have some negative impact on the environment. By far the most significant externality is air pollution. At present the most relevant and widespread form of European regulation is the application of technical emission standards prescribed by the 1988 Large Combustion Plant Directive for $\mathrm{SO}_{2}, \mathrm{NO}_{x}$ and TSP (LCPD). The proposal of a European $\mathrm{CO}_{2}$ tax has long been debated and no formal agreement has never been reached.

As elsewhere in the world, the European electricity sector is undergoing a substantial restructuring process. In 1996 a European Directive set goals and the modalities of the liberalisation and of the integration of the national electricity markets (Directive 96/92/EC). After 2006, all consumers will be admitted to the market. Member States are required to allow access to their electricity sector by means of non-discriminatory pricing of electricity transmission, and by means of non-discriminatory procedures for construction of new generation capacity. The presence of very large producers in some European countries coupled with a sub-optimal international transmission capacity will most probably lead to monopolistic competition rather than perfect competition in the transition phase.

In this paper we analyze the interaction between environmental policy and market liberalisation in Europe with a multi-country, dynamic partial equilibrium model for the European electricity market. We study two questions. First we try to assess what are the likely effects of the degree of competition on the state of the environment. Second we examine whether, in the imperfect competition case, it pays for a country to relax its environmental policy as predicted by the strategic trade literature.

In section 2 we review the theoretical and applied literature. In section 3 we present our model. In section 4 we study the effect of the degree of competition on the state of the environment. In section 5 we study the effects of unilateral deviations of environmental policy. Section 6 concludes. 


\section{NON-COMPETITIVE ELECTRICITY MARKETS AND ENVIRONMENTAL POLICY: INSIGHTS FROM THEORY}

A non-competitive market for electricity in Europe has important consequences for the way environmental policies can be implemented.

Trade under oligopolistic competition is characterised by positive profits. This provides an incentive to national governments to help domestic firms earn higher profits in the international arena. To this purpose, indirect commitment devices may be used when explicit trade policies ${ }^{4}$ are forbidden by trade agreements. National environmental policies have a direct influence on production costs of firms. Given the objective differences in the environmental situation of each country, their strategic use cannot easily be detected and prohibited. Thus, environmental policy makes a good candidate for an indirect trade policy device. From this idea stems quite a large literature on the interaction between environmental policy and trade. The first applications are due to Barrett (1994) for environmental standards and Conrad $(1993,1995)$ for taxes. These studies show that, compared to first best policies based on the rule that equates marginal social benefit to marginal social cost, environmental policies chosen by governments in the Nash equilibrium are tougher under Bertrand competition and less stringent under Cournot competition.

The theoretical models used in this strand of literature are in general very simple, with just two countries, one producer per country, homogeneous products, a single technology, domestic pollution and the whole output sold to a third country. Kennedy (1994) shows that including domestic consumers and transboundary pollution in the analysis compounds somehow the incentives of domestic governments to distort environmental policy. On one hand, governments would be happier if domestic consumers could be satisfied by foreign production: in presence of limited transboundary pollution, domestic damages would then decrease. On the other hand, governments are still interested in relaxing local environmental polices, thus expanding domestic market shares both for strategic reasons and because part of the resulting environmental damage would be shifted away by transboundary pollution. The overall incentive should be in general ambiguous, but in the specification chosen by Kennedy the second strategic effect prevails.

Technology choice and capacity setting are particularly important for the electricity sector, because electricity can be generated using different technologies, each of them

\footnotetext{
4 Brander and Spencer (1985) analyse the rent-shifting behaviour of two governments, which try to support their national producer in an international Cournot duopoly, by means of export subsidies. These subsidies act as devices that commit national producers to a certain level of output and hence to a higher market share than the one they would have achieved in a simple Cournot equilibrium. 
characterised by different costs and by different impacts on the environment. The available capacity of these technologies determines the response of the firms to environmental policy. Also, generation and transmission capacity licensing can be powerful strategic instruments in the hands of the governments.

These issues have not yet been studied in a theoretical framework. However at least the generation capacity aspects and the differences in environmental impacts among technologies, are related to those studied in the literature on strategic innovation and the environment (for instance Ulph (1994) Ulph (1996), and Ulph and Ulph (1996). In these papers, a role analogous to the one of capacity investments is played by R\&D expenditures. The first two papers consider respectively process and environmental (i.e. emission-reducing) R\&D. The third paper considers them jointly, proving that they have the same distortionary effect on environmental policy. In general, however, it remains ambiguous whether this will lead to environmental policies that are stricter or more lax than first best ones. Finally, the dynamic analysis by Feenstra (1998) considers explicitly the role of investments, but her analysis is confined to the case of a single technology.

The theoretical literature shows that governments have indeed incentives to distort their environmental policies in an international oligopolistic market, but the magnitude and the direction of the incentives remain ambiguous. Moreover, theoretical models necessarily give an oversimplified depiction of the reality, and thus cannot capture all the complexity of the European electricity sector.

\section{MODELLING ELECTRICITY MARKETS AND ENVIRONMENTAL POLICY}

\section{1. Existing models}

In the empirical literature, we have either models considering environmental policy within a perfectly competitive European or American electricity market, or imperfectly competitive models of the electricity market where environmental policy plays no role.

Examples of the first kind of models are Holster (1997) for the European market and Palmer et al. (2001) for the American market. The first model compares a combined $\mathrm{CO}_{2} /$ Energy tax policy set by the European Commission with a $\mathrm{CO}_{2}$ tax set independently by a national government alone, finding the latter to be ineffective. The second model considers the interactions between the liberalisation of the American electricity market and two versions of a $\mathrm{NO}_{x}$ emission cap (seasonal and annual). In particular they analyse the 
welfare impacts and cost effectiveness of these two policies under "limited restructuring", whereby some States retain price regulation, and under "nationwide restructuring" whereby perfect competition is assumed for the whole country. They find, unsurprisingly, that the annual cap under nationwide restructuring dominates the other scenarios where either liberalisation or environmental policy (or both) is incomplete ${ }^{5}$.

Some national electricity models explicitly include imperfect competition ${ }^{6}$. For instance, Green and Newbery (1992) describe the deregulated English spot market. Their model does not consider investment decisions. Their aim is to assess whether the deregulation actually implemented in the United Kingdom in 90's is preferable to a regulated setting. It turns out that either regulation or a more fragmented structure would be advisable, and that the duopolistic market engendered by the reform fails to attain the Bertrand outcome the British government expected. Kemfert (1999) presents a Cournot model of the German electricity market. She finds that such setting gives a more plausible representation of the German market than downright perfect competition.

Wei and Smeers (1996, parts I and II)(, consider an imperfectly competitive electricity market for three European Countries under alternative assumptions regarding short run price determination: either optimal spot pricing or second lowest marginal cost pricing. These studies have a two stage structure: first, a long run Cournot equilibrium in capacities is computed, then prices and output are determined according to the institutional assumptions regarding the short run price setting. Their representation of the European electricity market however is too sketchy to derive any policy conclusion, and they are mostly interested in demonstrating that their algorithm reaches a unique equilibrium.

The only model we are aware of that assesses the European environmental policy within an imperfect competition framework is Böhringer et al. (2001). They present a general equilibrium model for Germany and consider, like Holster (1997) a unilateral introduction of a $\mathrm{CO}_{2}$ tax. They find that the resulting shift towards less carbon-intensive industries is more pronounced under imperfect than under perfect competition, but their cost appraisal does not yield clear-cut results. They assume that market power in the electricity sector is rather limited, positioning de-facto this paper at the borderline between perfect competition and oligopolistic competition analysis. Most importantly their representation of

\footnotetext{
5 Welsch (1998) analyses the consequences of a phase-out of nuclear power generation in Germany within a perfect competition, general equilibrium model of the European economy. Although it is not directly concerned with environmental policy, Welsch (1998) shows that renouncing to the nuclear technology in Germany brings about a substantial increase in Germany's $\mathrm{CO}_{2}$ emissions, and concludes that the rationale for such policy should be sought in politics rather than in economics.

${ }^{6}$ A survey of these models is provided by Smeers (1997).
} 
oligopolistic behaviour relies on exogenous mark-ups rather than on an explicit gametheoretic model.

\subsection{A simple description of our model.}

We present here a simplified version of our model. A description of the full model is provided in Appendix A. In this Section we focus on the simple problem of two countries, labelled Home and Foreign, that host each an electricity producer, and that are interconnected by two international transmission lines with fixed capacity $\bar{Q}_{H F}$ and $\bar{Q}_{F H}$. The first line conveys electricity from the Home Country to the Foreign Country, the second line is used for electricity flowing in the opposite direction. Using the international transmission lines involves a cost of $u$ Euro/MWh for the seller.

Each producer can generate electricity by means of two technologies, a clean one (labelled $c$ ), and a dirty one (labelled $d$ available in capacities $X_{c}, X_{d}$ and $Y_{c}, Y_{d}$, respectively in the Home and Foreign Country. Each unit of output from clean plants $x_{c}\left(y_{c}\right)$ emits $e_{c}$ tons of pollutant; each unit of output from dirty plants $x_{d}\left(y_{d}\right)$ emits $e_{d}\left(e_{d}>e_{c}\right)$ tons of pollutant. Electricity can be generated at a cost of $c_{c}$ Euro/MWh using the clean technology, and at a cost of $c_{d}$ Euro/MWh using the dirty technology.

We consider a three-stage game. In the environmental policy stage, governments set their environmental policy. In the investment stage, firms set their generation capacity for both technologies. In the production stage firms compete, taking as given their available capacity and the environmental policy.

\subsubsection{The Production Stage}

In the production stage, firms minimise the cost of producing any output level $Q_{i}$, and choose how much to produce, and where to sell their production, in order to maximise their profits, for given capacity levels $\bar{X}_{c}, \bar{X}_{d}$ and $\bar{Y}_{c}, \bar{Y}_{d}$. We assume that each country sells on the domestic market $Q_{i i} \mathrm{MWh}$ and $Q_{i j} \mathrm{MWh}$ on the rival country's market, where $i, j=H, F$ and $Q_{i}=Q_{i i}+Q_{i j}$. Firms are subject to environmental policies in the form of taxes per unit of emissions $t_{H}, t_{F}$ (and/or emission standards $\bar{e}_{H}$ and $\bar{e}_{F}$ ) respectively in the Home Country and in the Foreign Country. 
The cost function to be minimised by the Home firm is

$C\left(Q_{H}, t_{H}, \bar{e}_{H}\right)=c_{H}^{c} x_{H}^{c}+c_{H}^{d} x_{H}^{d}+t_{H}\left(e_{H}^{c} x_{H}^{c}+e_{H}^{d} x_{H}^{d}\right)$, subject to:

$x_{H}^{d} \leq \bar{X}_{H}^{d}$

$x_{H}^{c} \leq \bar{X}_{H}^{c}$

$x_{H}^{c}+x_{H}^{d} \geq Q_{H} ;$

$e_{H}^{c} x_{H}^{c}+e_{H}^{d} x_{H}^{d} \leq \bar{e}_{H}$

We assume that the solution to this production problem can be represented by a function

$$
C\left(Q_{H}, t_{H}, \bar{e}_{H}, \bar{X}_{c}, \bar{X}_{d}\right)
$$

Having allocated production efficiently between the two technologies, the two firms compete on the international market. Under Cournot competition, this means that each firm maximises its profits taking into account production and export decisions of its opponent. The profit function to be maximised by the Home firm is:

$\Pi_{H}\left(Q_{H}, Q_{H F}, Q_{F}, Q_{F H}, t_{H}, \bar{e}_{H}, \bar{Q}_{H F}, u, \bar{X}_{c}, \bar{X}_{d}\right)=R\left(Q_{H}, Q_{H F}, Q_{F}, Q_{F H}\right)-C\left(Q_{H}, t_{H}, \bar{e}_{H}, \bar{X}_{c}, \bar{X}_{d}\right)-u Q_{H F}$

subject to $Q_{H F} \leq \bar{Q}_{H F}$, and taking as given $Q_{F}$ and $Q_{F H}$.

A Cournot equilibrium for this stage of the game, is a vector $\left[Q_{H}^{*}, Q_{H F}^{*}, Q_{F}^{*}, Q_{F H}^{*}\right]$ such that $\left[Q_{H}^{*}, Q_{H F}^{*}\right]$ is a best response to $\left[Q_{F}^{*}, Q_{F H}^{*}\right]$ and vice versa, given

$u, t_{H}, t_{F}, \bar{e}_{H}, \bar{e}_{F}, \bar{Q}_{H F}, \bar{Q}_{F H}, \bar{X}_{H}^{c}, \bar{X}_{H}^{d}, \bar{X}_{F}^{c}, \bar{X}_{F}^{d}$. The equilibrium pay-off for the Home Country is then $\Pi_{H}^{*}=\Pi_{H}^{*}\left(u, t_{H}, t_{F}, \bar{e}_{H}, \bar{e}_{F}, \bar{Q}_{H F}, \bar{Q}_{F H}, \bar{X}_{H}^{c}, \bar{X}_{H}^{d}, \bar{X}_{F}^{c}, \bar{X}_{F}^{d}\right)$.

\subsubsection{The Investment Stage}

In the investment stage, firms set the capacities of their plants taking as given the environmental policies of the governments, in order to maximise profits for the corresponding Cournot equilibrium. In other words, in this stage firms commit to a generation capacity level that would put them in the best conditions to compete. In our numerical model, the commitment to an optimal level of investment will be characterised by the assumption of open-loop strategies ${ }^{7}$.

\footnotetext{
7 We prefer to focus on open-loop equilibria both because they are numerically more tractable, and because we intend to stress the commitment properties of investments.
} 
The Home firm chooses $X_{H}^{c}, X_{H}^{d}$ in order to maximise

$\tilde{\Pi}_{H}=\Pi_{H}^{*}\left(u, t_{H}, t_{F}, \bar{e}_{H}, \bar{e}_{F}, \bar{Q}_{H F}, \bar{Q}_{F H}, X_{H}^{c}, X_{H}^{d}, X_{F}^{c}, X_{F}^{d}\right)-S\left(X_{H}\right)$,

where $S\left(X_{H}\right)=S\left(X_{H}^{c}, X_{H}^{d}\right)$ is the investment cost.

A Nash equilibrium for this stage of the game, is a vector $\left[X_{H}^{c^{*}}, X_{H}^{d^{*}}, X_{F}^{c^{*}}, X_{F}^{d^{*}}\right]$ such that $\left[X_{H}^{c^{*}}, X_{H}^{d^{*}}\right]$ is a best response to $\left[X_{F}^{c^{*}}, X_{F}^{d^{*}}\right]$ and vice versa, given $u, t_{H}, t_{F}, \bar{e}_{H}, \bar{e}_{F}, \bar{Q}_{H F}, \bar{Q}_{F H}$. The ex-ante equilibrium pay-off for the Home Country is then $\tilde{\Pi}_{H}^{*}=\tilde{\Pi}_{H}^{*}\left(u, t_{H}, t_{F}, \bar{e}_{H}, \bar{e}_{F}, \bar{Q}_{H F}, \bar{Q}_{F H}\right)$.

\subsection{The Environmental Policy Stage}

In the environmental policy stage, governments set their environmental policies in a noncooperative way. The Home government's objective function is the sum of domestic consumer surplus (CS), domestic firms' profits, and domestic tax revenues, minus domestic environmental damages $D^{H}\left(e_{H}\right)$ :

$$
\begin{aligned}
& W_{H}\left(Q_{H}, Q_{H F}, Q_{F}, Q_{F H}, t_{H}, \bar{e}_{H}, \bar{Q}_{H F}, X_{H}, u\right)= \\
& \operatorname{CS}\left(Q_{H}, Q_{F H}\right)+R\left(Q_{H}, Q_{H F}, Q_{F}, Q_{F H}\right)-C\left(Q_{H}, t_{H}, \bar{e}_{H}\right)-u Q_{H F}-S\left(X_{H}\right)+t_{H} e_{H}-D^{H}\left(e_{H}\right) .
\end{aligned}
$$

The Foreign government has an analogous objective function.

From the Trade and Environment literature, we expect that governments do not apply first best environmental policies. Instead, they would distort them in order to increase domestic welfare at the expense of the rival country ${ }^{8}$.

Governments face conflicting incentives stemming from the consumers' surplus part of their objective function. Consumers' surplus depends partly on electricity imports, and partly on domestic production. As pointed out by Kennedy (1994), in a Cournot setting, incrementing the import-dependent component of consumers' surplus calls for more strict environmental policies, because this would favour the foreign producer and would allow domestic consumers to import more. On the other hand, incrementing domestic consumers' surplus by means of domestic production calls for less stringent environmental policies, because this favours the domestic producer. In our model, international trade is

8 Note that, in principle, if the jurisdiction over a line pertains to the country that receives the electricity, governments could use the access to the national grid as an extra trade policy tool. However, the Internal Market in Electricity Directive 96/62/EC explicitly calls for non-discriminatory access to national grids. Note that it does not require the existing transmission capacity to be expanded, only fair and transparent rules for accessing the national grids. In our model, this is taken into account by assuming a single price $u$ for international transmission of electricity, and fixed transmission capacity. 
bounded by the capacity of international connection lines. This limits the amount of electricity that can be imported, and hence the incentive for the governments to set overly restrictive policies. We would then expect that the concern for the welfare of consumers would rather push the governments towards less strict environmental policies.

The incentives to promote domestic profits are more straightforward. Each government would set less stringent environmental policies if this contributes to commit the national producer to lower production costs (without generating excessive environmental damages).

In our simulations the environmental policy stage is not modelled in an extensive way. We content ourselves with evaluating unilateral deviations from first-best environmental policies, without characterising a full Nash equilibrium in the policy game.

\subsection{Model implementation and Data Used}

The focus of the model is on the electricity sector of Belgium, the Netherlands, France and Germany, for a time horizon of 35 years.

Whilst we intend to capture many of the differences among the four countries by means of country-specific data, we do take some simplifying assumptions. In particular, we assume that the shape of the demand functions and the way consumers allocate their purchases of electricity through sub-periods (peak, off peak) do not depend on their place of residence. Moreover, in each country there is just one producer which can generate electric power using several plants. Whilst this is a realistic hypothesis for France and Belgium, where market concentration is very high, it amounts to a serious simplification of the Dutch and German electricity industry. At least three large generators can be found there. Our hypothesis of a single national producer means that they behave like a cartel.

We also assume that fuel prices and relative growth rates are determined on the world market and are exogenous. Fuel prices are shown in Figure 1. Finally, given the unavailability of transmission cost data, we set transmission costs at 16.7 Euro/MWh for international lines and 4.5 Euro/MWh for national lines. These assumptions are obtained by calibration of electricity prices in 2000.

Producers have at their disposal the technologies described in Table 1 . In a costminimizing framework, from Figure 1 and Table 1, one would expect that coal and nuclear plants, given their low running costs to be used first, whereas gas turbines would be more likely used to cope with peak demand. As to investments in new capacity, we expect the relationship between investment on one hand and fuel and other variable costs on the other, to play a major role in the technology choices of the producers, with expensive 
units installed only if they guarantee low operation costs. We assume moreover that these unit production and investment costs are not influenced by the market regime.

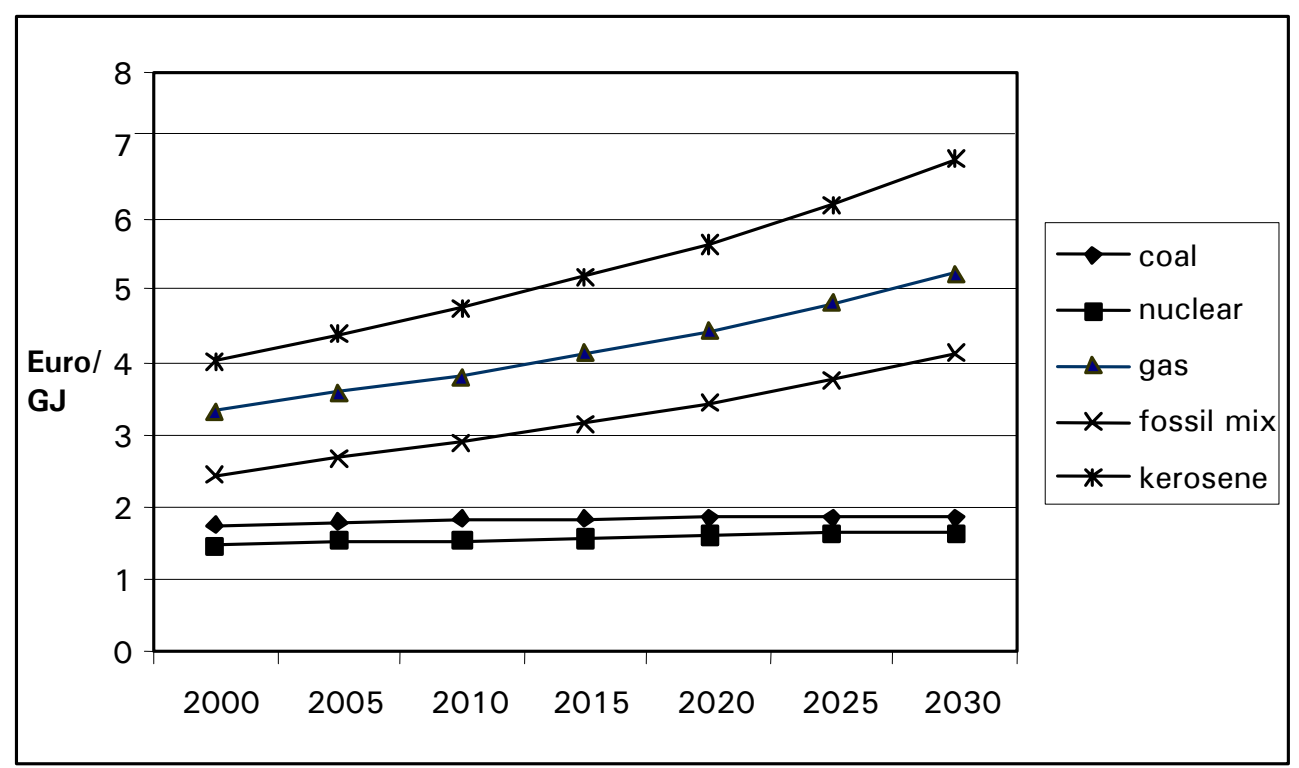

Figure 1: Fuel prices

The four countries remain very different from each other in several respects. In particular, the electricity demanded in 2000 , the installed capacity for each technology in 2000 , the external costs of each pollutant, the share of small consumers in total demand (and, consequently, average demand elasticity ${ }^{9}$ ), the demand's growth rates, and finally the preexisting environmental policies are different in each country. For demand data, we draw upon the estimates used in the European Union Energy Outlook to 2020.

\footnotetext{
${ }^{9}$ We assume point elasticity of -0.40 for residential consumers and -0.70 for large consumers.
} 


\begin{tabular}{|c|c|c|c|c|c|c|c|c|c|c|}
\hline Technology & Fuel Type & $\begin{array}{l}\text { Efficiency } \\
\text { MWh/GJ }\end{array}$ & $\begin{array}{l}\text { Availability } \\
\text { factor } \\
(\%)\end{array}$ & $\begin{array}{l}\mathrm{NO}_{\mathrm{x}} \\
\text { Emissions } \\
\text { (mg/kWh) }\end{array}$ & $\begin{array}{l}\mathrm{SO}_{2} \\
\text { Emissions } \\
\text { (mg/kWh) }\end{array}$ & $\begin{array}{l}\mathrm{CO}_{2} \\
\text { Emissions } \\
\text { (g/kWh) }\end{array}$ & $\begin{array}{l}\text { TSP } \\
\text { emissions } \\
\text { (mg/kWh) }\end{array}$ & $\begin{array}{l}\text { Fixed } \\
\text { O\&M } \\
\text { Costs } \\
\text { (EURO/ } \\
\text { kWh }\end{array}$ & $\begin{array}{l}\text { Investment } \\
\text { costs } \\
\text { (EURO/ } \\
\text { kWh) }\end{array}$ & $\begin{array}{l}\text { Variable } \\
\text { costs } \\
\text { (mEURO/ } \\
\text { kWh) }\end{array}$ \\
\hline Old Coal & Coal & 2.6 & 84 & 4101 & 6021 & 890 & 520 & 52 & 1428 & 2.1 \\
\hline New Coal & Coal & 2.32 & 82 & 2005 & 59 & 793 & 93 & 45 & 1444 & 1.9 \\
\hline $\begin{array}{l}\text { Nuclear } \\
\text { Plant }\end{array}$ & Nuclear & 2.22 & 85 & & & & & 51 & 2530 & \\
\hline $\begin{array}{l}\text { Old Gas } \\
\text { Turbine }\end{array}$ & nat. gas & 3.57 & 0.9 & 1607 & 13 & 720 & & 20 & 476 & 5.8 \\
\hline $\begin{array}{l}\text { Gas STAG } \\
\text { turbine }\end{array}$ & nat. gas & 1.87 & 85 & 337 & 7 & 377 & & 29 & 619 & 1.4 \\
\hline $\begin{array}{l}\text { Oil \& Gas } \\
\text { conventional }\end{array}$ & Mix & 2.38 & 84 & 1122 & 4284 & 643 & 476 & 30 & 646 & 1.7 \\
\hline $\begin{array}{l}\text { Gas turbine } \\
\text { (kerosene) }\end{array}$ & Kerosene & 3.57 & 90 & 1735 & 1799 & 720 & 143 & 20 & 476 & 1.7 \\
\hline Hydro power & Hydro & 2.6 & 89 & & & & & 3 & 2375 & 1.7 \\
\hline Wind turbine & Wind & 2.60 & seasonal & & & & & 28 & 1244 & \\
\hline $\begin{array}{l}\text { Waste } \\
\text { incinerator }\end{array}$ & $\begin{array}{l}\text { mun. } \\
\text { waste }\end{array}$ & 2.38 & 84 & 2142 & 823 & 643 & 95 & 30 & 646 & \\
\hline $\begin{array}{l}\text { STAG for } \\
\text { cogeneration }\end{array}$ & nat. gas & 2.61 & 80 & 470 & 9 & 526 & & 25 & 836 & \\
\hline
\end{tabular}

Table 1: Power plant characteristics

As a measure of the degree of noxiousness of different pollutants, we use the ExternE (European Commission (1999)) estimates of the external damages of air emissions. Given the linearity of our damage function, these estimates can be regarded as marginal damages. These estimates are reported in Table 2 along with other country-specific data, and are used as a base for the ex-post welfare evaluation of the various scenarios examined. In most of our analysis, we consider only environmental damages caused by emissions of air pollutants and hence we disregard other external effects le.g. accident risk for nuclear plants), because these damage estimates are very low in ExternE. For nuclear power they amount to about 4.2 Euro/MWh in Belgium, 7.2 Euro/MWh in the Netherlands, 5.2 Euro/Mwh in Germany, and only 2.5 Euro/MWh in France. These figures are one order of magnitude lower than those for coal under equivalent aggregation assumptions (65 Euro/MWh in Belgium, 55 Euro/MWh in the Netherlands, 55 Euro/MWh in Germany, 68 Euro/MWh in France). 
The Opening of the European Electricity Market and Environmental Policy: Does the Degree of Competition Matter?

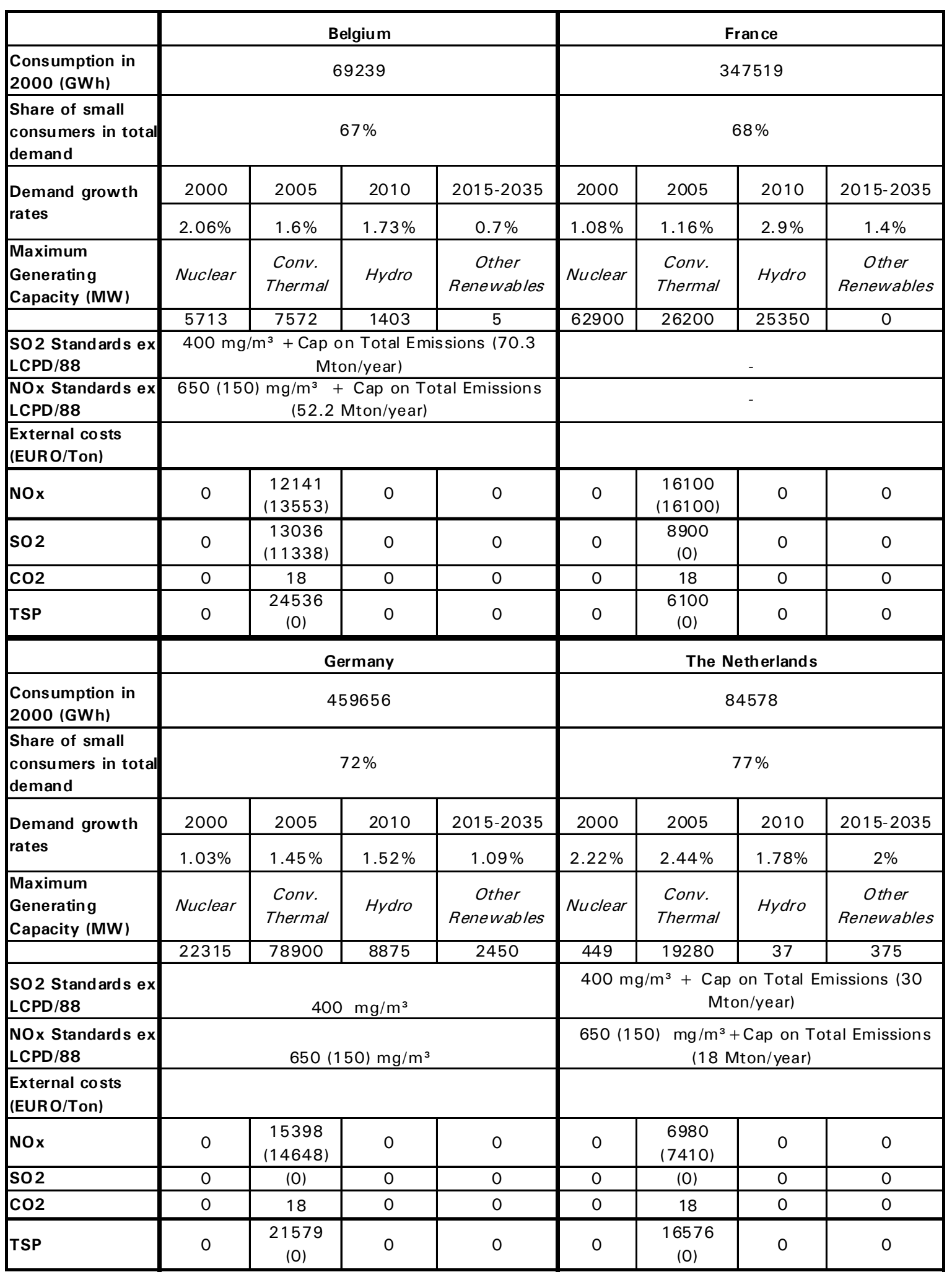

Table 2: Country-specific data ${ }^{10}$.

10 Sources: European Commission, UNIPEDE, Oosterhuis et al., authors' calculations and ExternE. The figures in brackets refer to gas plants. The estimate for $\mathrm{CO}_{2}$ emission damage refers only to a mid-low estimate of global warming damages, the sole category of damages considered for this pollutant in the ExternE project. 
From Table 2, one notices that the modalities of electricity generation differ strongly among countries. For instance, France relies more heavily on nuclear generation than the other countries; gas powered plants are more widespread in the Netherlands, whereas the share of coal plants is still important in Germany.

Finally, we assume different interconnection capacities between each pair of countries. Given the lack of available data, we derived our assumed capacities from the maximum monthly value of load flows between countries ${ }^{11}$ and we increased those figures by $10 \%$. These capacities are shown in Table 3 . We assumed the same capacity for each flow direction, no constraints for domestic transmission, and no direct interconnection between France and the Netherlands ${ }^{12}$.

\begin{tabular}{|l|llll|}
\hline & Belgium & Germany & France & The Netherlands \\
\hline Belgium & $+\infty$ & 1550 & 2000 & 1350 \\
Germany & 1550 & $+\infty$ & 2600 & 3300 \\
France & 2000 & 2600 & $+\infty$ & 0 \\
The Netherlands & 1350 & 3300 & 0 & $+\infty$ \\
\hline
\end{tabular}

Table 3: Capacity (MW) of international transmission lines

\subsection{The baseline}

We will use three alternative assumptions on market regime: Perfect Competition, Price Regulation for the whole time horizon and Cournot Competition. All scenarios have a common starting point: a regulated price in the period 2000-2004; after this period, each scenario then jumps to one of the three market regimes for the rest of the horizon. Instead of presenting each environmental scenario in each market regime in turn, we prefer to take the first two market regimes as alternative benchmarks and to focus directly on the differences between the Cournot outcome and these benchmarks in each scenario.

\footnotetext{
${ }^{11}$ Load flows between countries at 3:00 and 11:00 a.m., as reported in the 1999 UCTE Statistical Yearbook.

12 See Appendix A for a detailed description of transmission capacity constraints. 
In the baseline we assume that the following environmental regulation is in place (see Table 4):

\begin{tabular}{|l|l|}
\hline Environmental Problem & Regulation assumed in baseline \\
\hline $\mathrm{NO}_{x}, \mathrm{TSP}, \mathrm{SO}_{2}$ & $\begin{array}{l}\text { Large Combustion Plant Directive (1988) implemented } \\
\text { by member state under the form of national bubbles, } \\
\text { the caps stay fixed for the whole horizon }\end{array}$ \\
\hline $\mathrm{CO}_{2}$ & $\begin{array}{l}\text { We assume that there is a damage of 18 Euro/ton for } \\
\text { the period 2010-2034, a carbon tax CAN be } \\
\text { introduced. }\end{array}$ \\
\hline Nuclear safety & $\begin{array}{l}\text { We assume that the EU legislation on nuclear safety is } \\
\text { observed }\end{array}$ \\
\hline Renewables & No minimum quota's are imposed \\
\hline
\end{tabular}

Table 4: Environmental regulation in the baseline

Compared to the benchmark there is only one environmental policy variable that will be changed: the unilateral tax on $\mathrm{CO}_{2}$ emissions in the electricity sector. We have assumed that there is a marginal damage of $\mathrm{CO}_{2}$ equal to 18 Euro/ton. This damage can be understood in two ways. First it can be seen as (discounted) climate change damage and second as the shadow cost of meeting the EU Kyoto obligation in Europe. Any $\mathrm{CO}_{2}$ reduction effort in the electricity sector comes down to a reduced call upon internationally traded carbon emission rights whose cost we fix at 18 Euro / ton.

We will later on use unilateral $\mathrm{CO}_{2}$ tax deviations to evaluate the incentives for national governments to deviate from a uniform European $\mathrm{CO}_{2}$ tax in a Cournot equilibrium. 


\section{POLICY SIMULATIONS}

\subsection{Who Benefits from Imperfect Competition?}

Before examining environmental impacts it may useful to compare briefly the three market regimes. We compare the perfect competition outcome with the Cournot outcome in Table 5. Our simulations confirm the traditional result that imperfect competition reduces aggregate welfare, and that the benefits stemming from monopoly profits and lower environmental damages are more than compensated by the decrease in consumers' surplus.

\begin{tabular}{|l|r|r|r|r|r|}
\hline \multicolumn{1}{|c|}{ Bn Euro } & \multicolumn{1}{|c|}{ B } & \multicolumn{1}{|c|}{$\mathrm{D}$} & \multicolumn{1}{|c|}{$\mathrm{F}$} & \multicolumn{1}{c|}{ NL } & TOTAL \\
\hline Consumer Surplus & -57.33 & -375.03 & -305.75 & -77.80 & -815.90 \\
\hline Producers Profits & 18.40 & 114.67 & 99.02 & 18.64 & 250.73 \\
\hline Taxes & 9.65 & 52.95 & 46.53 & 7.45 & 116.58 \\
\hline Damage SO2 & -2.38 & -69.62 & -2.26 & 1.73 & -72.52 \\
\hline Damage NOx & -2.32 & -84.74 & -15.88 & -0.15 & -103.10 \\
\hline Damage CO2 & -1.59 & -34.70 & -8.44 & -1.45 & -46.17 \\
\hline Damage TSP & -0.41 & -14.67 & -1.42 & 0.34 & -16.16 \\
\hline Environmental Damages & -6.70 & -203.72 & -28.00 & 0.47 & -237.95 \\
\hline Environmental taxes & 0 & 0 & 0 & 0 & 0 \\
\hline Social welfare & -22.58 & -3.69 & -132.19 & -52.18 & -210.64 \\
\hline
\end{tabular}

Table 5: Baseline case. Difference between Cournot and Perfect Competition.

Welfare outcomes (Bn Euro) $)^{13}$

Table 5 presents for the Baseline case, the cumulative welfare difference between the Cournot and the Perfect Competition outcomes. It includes consumer surplus of electricity consumers, producers profits, total tax revenues and revenues from $\mathrm{CO}_{2}$ taxes only, monetary damages of $\mathrm{CO}_{2}, \mathrm{SO}_{2}, \mathrm{NO}_{x}$ and TSP emissions and their total value.

From Table 5 one concludes that the most important welfare effect of Cournot Competition is the reduction in consumers' surplus. Consumers under Cournot Competition pay prices that are on average ${ }^{14} 45 \%$ higher than regulated prices in 2000 . The largest effects take place in the countries with the largest internal market, namely Germany and France. The main winners under Cournot Competition are of course the producers, whose profits increase considerably. Notice that profits are proportional to the size of the internal market of each country. This indicates that transmission capacity constraints provide

\footnotetext{
${ }^{13}$ A negative sign means that the Perfect Competition case has a larger value.

${ }^{14}$ Weighted average prices, where market shares are used as weights.
} 
strong local market powers to producers on their domestic markets. Not all the countries suffer to the same extent from imperfect competition. Germany has a rather dirty initial generation mix so that a reduction of domestic output gives large environmental benefits.

\begin{tabular}{|c|c|c|c|c|c|}
\hline & $\mathrm{B}$ & $\bar{D}$ & $\bar{F}$ & $\overline{\mathrm{NL}}$ & $\overline{\text { TOTAL }}$ \\
\hline Consumer Surplus & -47.64 & -309.27 & -236.38 & -62.62 & -655.90 \\
\hline Producers' Profits & 13.96 & 81.45 & 63.81 & 12.14 & 171.37 \\
\hline Taxes & 5.56 & 22.40 & 15.94 & 1.57 & 45.47 \\
\hline Damage SO2 & -2.37 & -69.11 & -1.44 & 1.63 & -71.29 \\
\hline Damage Nox & -2.32 & -82.69 & -13.55 & -0.14 & -98.70 \\
\hline Damage CO2 & -1.55 & -33.59 & -7.29 & -1.04 & -43.47 \\
\hline Damage TSP & -0.42 & -14.45 & -1.16 & 0.31 & -15.72 \\
\hline tht & -6.65 & -199.84 & -23.44 & 0.76 & -229.17 \\
\hline 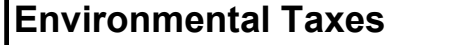 & 0 & 0 & 0 & 0 & \\
\hline Social Welfare & -21.46 & -5.58 & -133.19 & -49.67 & -209.90 \\
\hline
\end{tabular}

Table 6: Baseline case. Difference between Cournot Competition and Price Regulation. Welfare outcomes (Bn Euro) $)^{15}$

Table 6 compares Cournot Competition with Price Regulation. We find the same kind of results $^{16}$ as in Table 5 but differences are a little less marked, because under Price Regulation national firms retain an important profit margin. Profits under Cournot Competition remain by far the highest of the three market regimes considered.

Some international trade of electricity takes place in all market regimes. Given the strong similarity in trade patterns among regimes, we exemplify them by reporting only those under Cournot Competition in Figure 2.

\footnotetext{
${ }^{15}$ A negative sign means that the Price Regulation case has a larger value.

${ }^{16}$ The solver treats this case as a perfect competition model where the cost function has been shifted upw ards.
} 

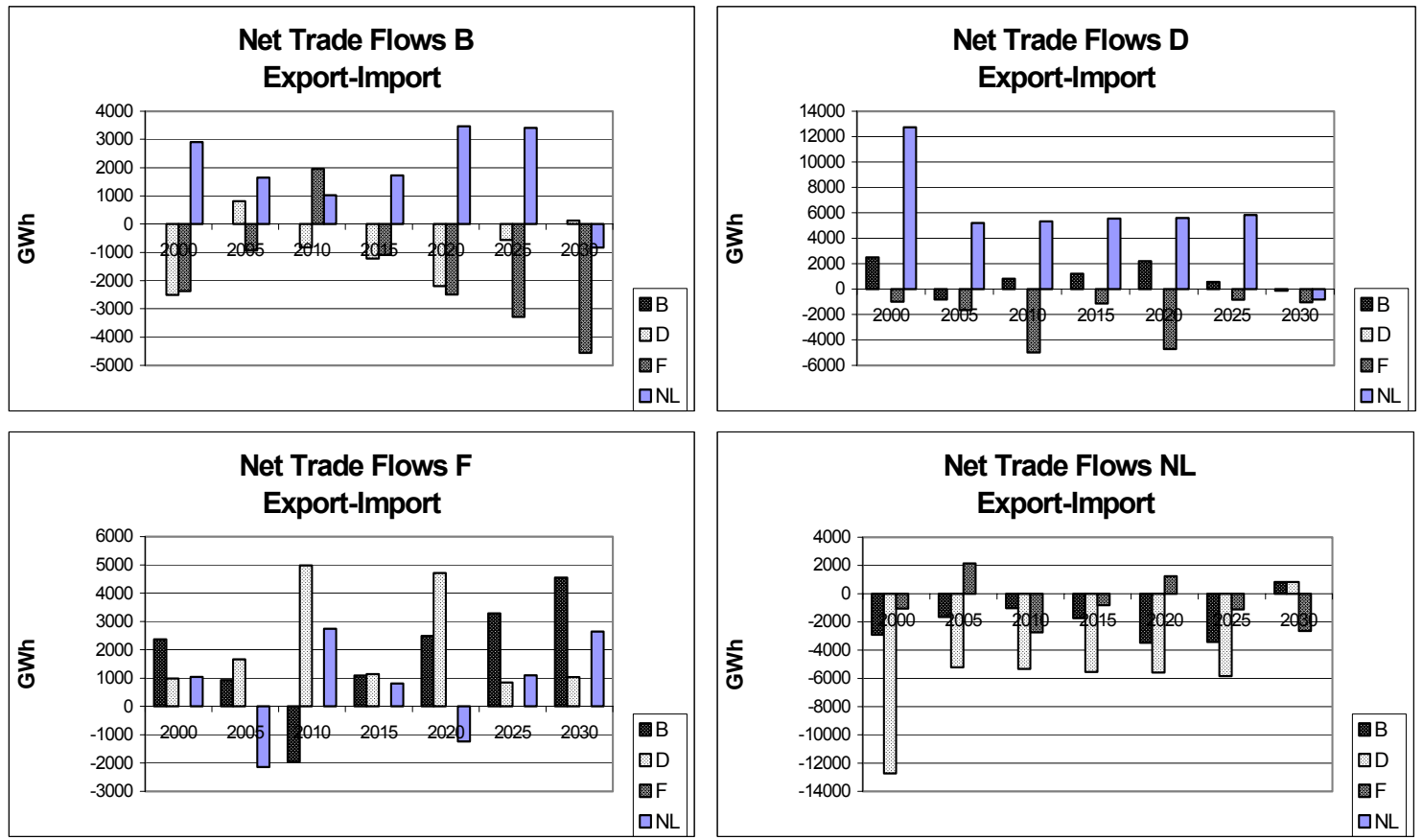

Figure 2: Baseline case. Net trade flows under Cournot Competition

Trade patterns are not very much affected by the kind of competition, and are particularly similar under Perfect Competition and Price Regulation. With the exception of France, trade balances are slightly higher in magnitude under Perfect Competition. France and Germany are net exporters of electricity, while Belgium and the Netherlands are net importers. In fact, Germany and France have much larger available capacities in cheap base load technologies than Belgium and the Netherlands and are always able to export some of their production.

\subsection{Does Imperfect Competition Help to Meet Environmental Targets?}

Given the partial equilibrium setting of our model, we must distinguish between targets clearly specified for the electricity sector, such as the Belgian and Dutch caps on $\mathrm{SO}_{2}$ and $\mathrm{NO} \mathrm{O}_{x}$ emission, and targets specified for the whole national economy, such as $\mathrm{CO}_{2}$ targets under the Kyoto Protocol. For the second type of targets, we measure the reduction in total $\mathrm{CO}_{2}$ emissions in the electricity sector.

From our computations it is clear that, whilst the Belgian and Dutch $\mathrm{NO}_{x}$ emission constraints are always binding in the Baseline scenario under Perfect Competition, their stringency declines under Cournot Competition. In particular, actual Belgian $\mathrm{NO}_{\mathrm{x}}$ emissions 
are below the target in the period 2005-2019, whereas $\mathrm{NO}_{x}$ emissions remain a binding constraint in the Netherlands in all periods but 2005-2009.

Quite the opposite story happens for $\mathrm{SO}_{2}$ emissions. The $\mathrm{SO}_{2}$ constraint is never binding in both countries under Perfect Competition, but becomes binding for the Netherlands in three periods under Cournot Competition.

This is illustrated in Figure 3 below. Cournot Competition brings about two effects that have a direct influence on the stringency of environmental policies: technology substitution and output reduction. Note that it is not granted that the first factor will lead to the adoption of less polluting technologies. In fact, from Table 5 one notices that environmental damages actually increase in the Netherlands under Cournot Competition. This is due to the fact that output reduction in this country mainly affects the investment in new nuclear, wind and gas plants (which have no or very low air emissions) while the use of waste incinerators and kerosene plants actually increases. Given the higher prices prevailing under Cournot Competition, the Dutch generator has to invest less in new baseload capacity. It is more profitable to invest in plants more suitable for peak-load generation, such as waste incinerators and kerosene plants, which bring about substantial emissions.

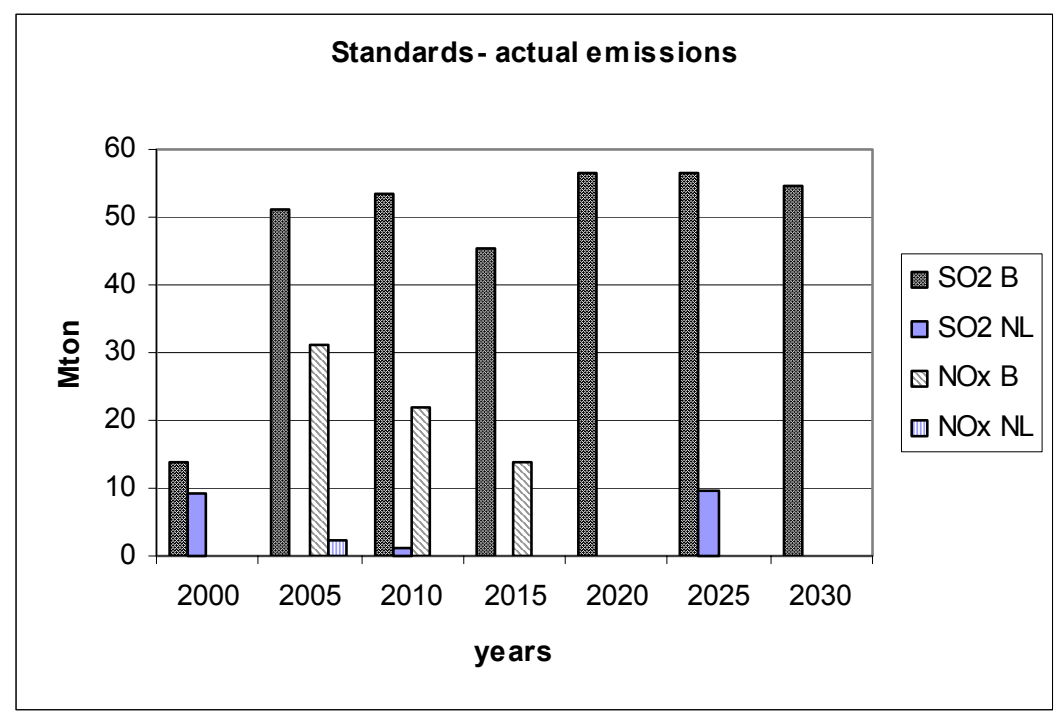

Figure 3: Baseline scenario. Emission reductions in excess of the targets for $\mathrm{SO}_{2}$ and $\mathrm{NO}_{x}$ under Cournot Competition 


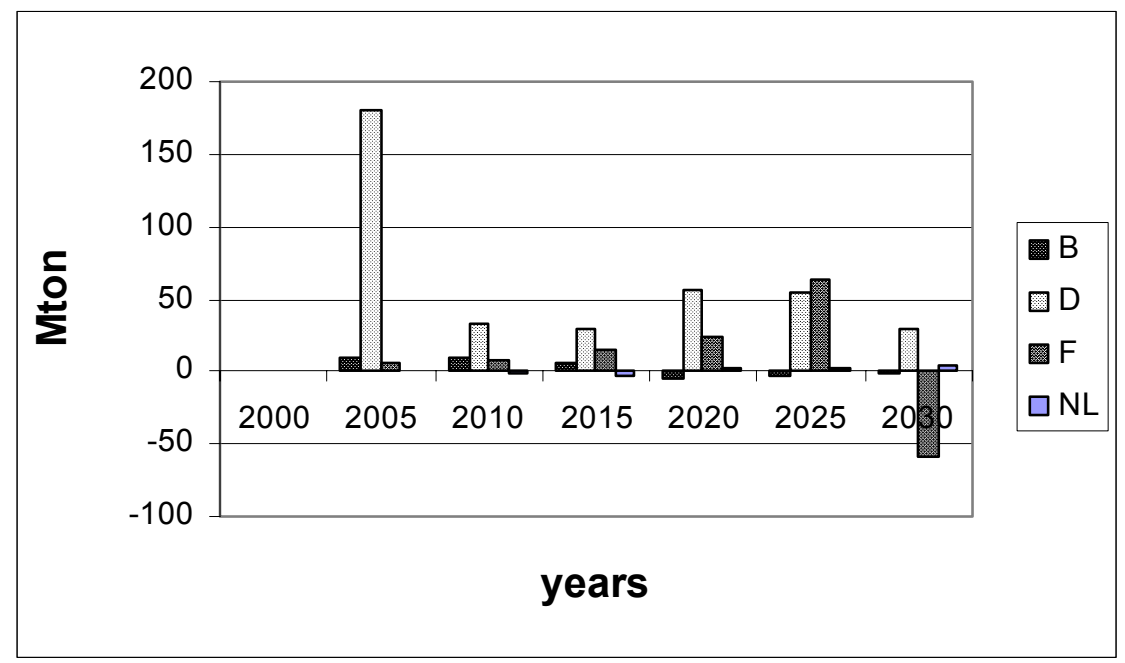

Figure 4: Baseline scenario. + European $\mathrm{CO}_{2}$ tax. Difference between $\mathrm{CO}_{2}$ emissions under Perfect versus Cournot Competition

Turning to $\mathrm{CO}_{2}$ emissions, Figure 4 illustrates the differences in $\mathrm{CO}_{2}$ emissions between Perfect and Cournot Competition in the baseline scenario to which we have added a $\mathrm{CO}_{2}$ tax. Figure 4 shows that, over the whole time horizon considered, the $\mathrm{CO}_{2}$ tax achieves more substantial $\mathrm{CO}_{2}$ emission reductions under Cournot Competition but this does not necessarily hold in each period and in each country. Compared to Cournot Competition, these emissions are slightly lower under Perfect Competition in Belgium from 2020 onwards, in the Netherlands between 2010 and 2019, while France has substantially lower emissions under Perfect Competition starting from 2030. This is due to an effect similar to the one that we have noticed taking place in the Netherlands for $\mathrm{SO}_{2}$ emissions. France in particular does not invest at all in new nuclear plants in this scenario under Cournot Competition, while it does invest in new nuclear capacity under Perfect Competition after 2025.

\begin{tabular}{|l|rrrrr|}
\hline & $\mathrm{B}$ & $\mathrm{D}$ & $\mathrm{F}$ & \multicolumn{2}{c|}{$\mathrm{NL}$} \\
\hline Consumers Surplus & -57.88 & -365.13 & -287.82 & -81.38 & -792.21 \\
Producers Profits & 19.60 & 116.90 & 91.83 & 22.64 & 250.98 \\
Taxes & 10.03 & 44.24 & 39.36 & 10.96 & 104.60 \\
Damage SO2 & -2.48 & -60.23 & -1.81 & 0.44 & -64.08 \\
Damage NOx & -2.35 & -47.70 & -3.51 & -0.10 & -53.67 \\
Damage CO2 & -0.91 & -15.69 & -2.20 & -0.09 & -18.89 \\
Damage TSP & -0.41 & -10.58 & -0.25 & 0.08 & -11.16 \\
Environmental Damages & -6.15 & -134.20 & -7.78 & 0.32 & -147.81 \\
Environmental taxes & -0.66 & -10.66 & -2.01 & -0.06 & -13.39 \\
Social Welfare & -22.09 & -69.79 & -148.85 & -48.10 & -288.83 \\
\hline
\end{tabular}

Table 7: Baseline scenario. + European $\mathrm{CO}_{2}$ tax U-Kyoto Tax scenario. Difference between Cournot and Perfect Competition. Welfare outcomes (Bn Euro) 


\begin{tabular}{|l|rrrrr|}
\hline & \multicolumn{1}{|c}{$\mathrm{B}$} & \multicolumn{1}{c}{$\mathrm{D}$} & \multicolumn{1}{c}{$\mathrm{F}$} & \multicolumn{1}{l}{$\mathrm{NL}$} & \multicolumn{1}{c|}{ TOTAL } \\
\hline Consumer Surplus & -49.34 & -305.48 & -226.01 & -66.36 & -647.19 \\
Producers Profits & 15.61 & 87.09 & 60.54 & 15.82 & 179.06 \\
Taxes & 6.26 & 16.86 & 12.36 & 4.68 & 40.17 \\
Damage SO2 & -2.45 & -60.74 & -1.63 & 0.59 & -64.24 \\
Damage NOx & -2.34 & -47.35 & -2.60 & -0.11 & -52.38 \\
Damage CO2 & -0.90 & -15.41 & -1.67 & -0.17 & -18.15 \\
Damage TSP & -0.40 & -10.62 & -0.20 & 0.11 & -11.12 \\
Environmental Damages & -6.10 & -134.12 & -6.10 & 0.41 & -145.90 \\
Environmental Taxes & -0.65 & -10.35 & -1.52 & -0.09 & -12.61 \\
Social Welfare & -21.37 & -67.41 & -147.01 & -46.28 & -282.06 \\
\hline
\end{tabular}

Table 8: Baseline $+\mathrm{CO}_{2}$ tax scenario. Difference between Cournot and Price

Regulation. Welfare outcomes (Bn Euro)

As to the welfare effects of a European Kyoto tax, consider Table 7 and Table 8 . These tables present the same kind of results as in Table 5 and Table 6, respectively, under the hypothesis that a European tax on $\mathrm{CO}_{2}$ equal to half the (assumed) marginal damage of this pollutant (18 Euro/ton) is implemented in 2005-2009 and that a European tax on $\mathrm{CO}_{2}$ equal to the (assumed) full marginal damage is implemented from 2010 onwards. Comparing Table 7 with Table 5 one notices that the difference in welfare between the two market regimes increases with the implementation of a $\mathrm{CO}_{2}$ tax. This happens because correcting an externality unambiguously improves welfare under Perfect Competition. Under Cournot Competition, Pigouvian taxes should be coupled with a production subsidy in order to restore optimality. If used alone, they result in extra deadweight losses because the existing imperfect competition distortions are aggravated ${ }^{17}$. A similar argument explains what happens under Price Regulation. Comparing Table 7 with Table 8, one notices a slight decrease in the difference in welfare with respect to the Cournot case, when the comparison is drawn against price regulation instead of perfect competition. Under Price Regulation, firms have a small profit margin, and imposing a Pigouvian tax brings about a small deadweight loss ${ }^{18}$.

\footnotetext{
17 The implementation of a $\mathrm{CO}_{2}$ tax also helps meeting the $\mathrm{SO}_{2}$ and $\mathrm{NO} \times$ targets. From the comparison of Table 5 with Table 7, one notices that the decrease in damages from these pollutants is more pronounced in Belgium under a $\mathrm{CO}_{2}$ tax, whereas in the Netherlands the increase in $\mathrm{SO}_{2}$ damages is smaller. This happens because of the correlation between emission factors across technologies. A plant that emits significant amounts of $\mathrm{CO}_{2}$ is likely to have significant $\mathrm{SO}_{2}$ and $\mathrm{NO}_{x}$ emissions as well. Therefore a policy aimed at reducing $\mathrm{CO}_{2}$ emissions, in absence of specific abatement technology, will lead to reduction in the emissions of other pollutants, through output reductions from the polluting plants. This holds both under Perfect and Cournot competition.

18 Trade patterns are not very much affected by the presence of a $\mathrm{CO}_{2}$ tax. Since the implementation of a $\mathrm{CO}_{2}$ tax results in higher prices and lower demand, trade balances are slightly higher in magnitude in the Baseline scenario.
} 


\subsubsection{Is there an Incentive for Individual Countries to Relax Their Environmental Policy as Predicted by the Strategic Trade Literature?}

In order to fully answer this question, one should in principle compute the Nash equilibrium of the game in which each country sets its environmental policies taking as given the environmental policies of the other countries ${ }^{19}$. We do not take this option, both because it is computationally very demanding, and because, within the European Union, countries do not enjoy complete freedom in their environmental policy choices. The targets set in European Directives or in the international protocols heavily limit their strategy space. However, countries are given some leeway in the implementation of these targets. We ask ourselves, therefore, whether national governments would be interested in unilateral deviations from the $\mathrm{CO}_{2}$ tax set at the common marginal damage level (or opportunity cost level) of 18 Euro/ton. The results are shown in the following Figures and in the Tables presented in Appendix $\mathrm{B}^{20}$.

${ }^{19} \mathrm{Had}$ we assumed perfect foresight also on the part of governments, we would expect that only a government that can foresee welfare gains for its country would engage in strategic environmental policy distortions. However, a common result in the Trade and Environment literature is that distortionary policies lead to a prisoner's dilemma. In fact a country adopting a commitment device to support its national producer would gain with respect to a free-trade outcome if it were the only one to take such option, while a free-trade outcome is superior to the Nash equilibrium where all the countries pre-commit. A myopic perspective is hence more appropriate.

20 In this section and in Appendix B we distinguish between "Social welfare only $\mathrm{CO}_{2}$ ", which takes into account only $\mathrm{CO}_{2}$ damages in the damage function and "Social Welfare", which takes into account damages from all air pollutants. This distinction has been introduced to highlight the fact that, in the EU-Kyoto Tax scenarios, a $\mathrm{CO}_{2}$ tax also reduces other emissions and this has relevance for the incentives to deviate. 
The Opening of the European Electricity Market and Environmental Policy: Does the Degree of Competition Matter?

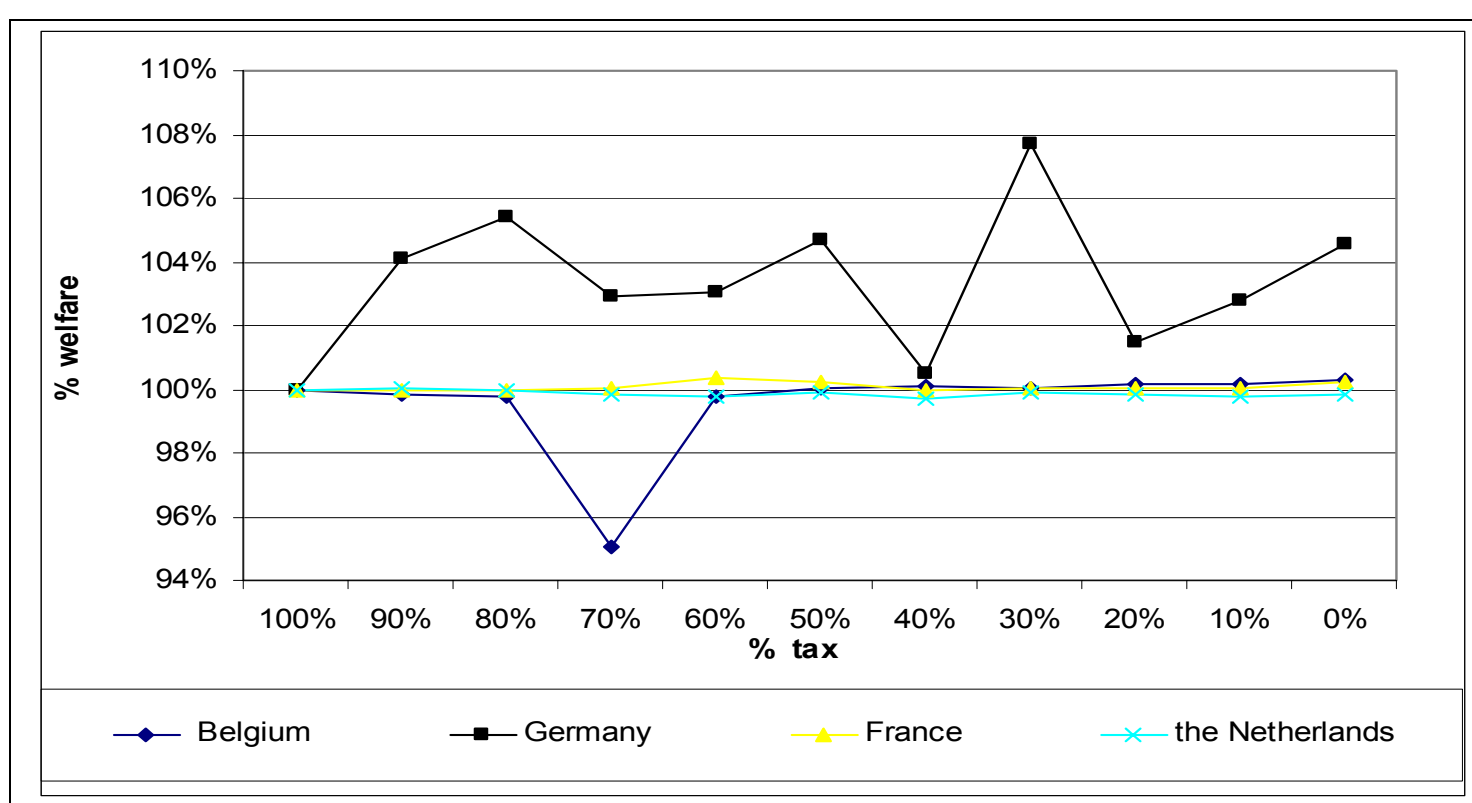

Figure 5a: Welfare effects of unilateral deviations in Belgium from $\mathrm{CO}_{2}$ tax under Cournot competition, damages from all pollutants included in welfare.

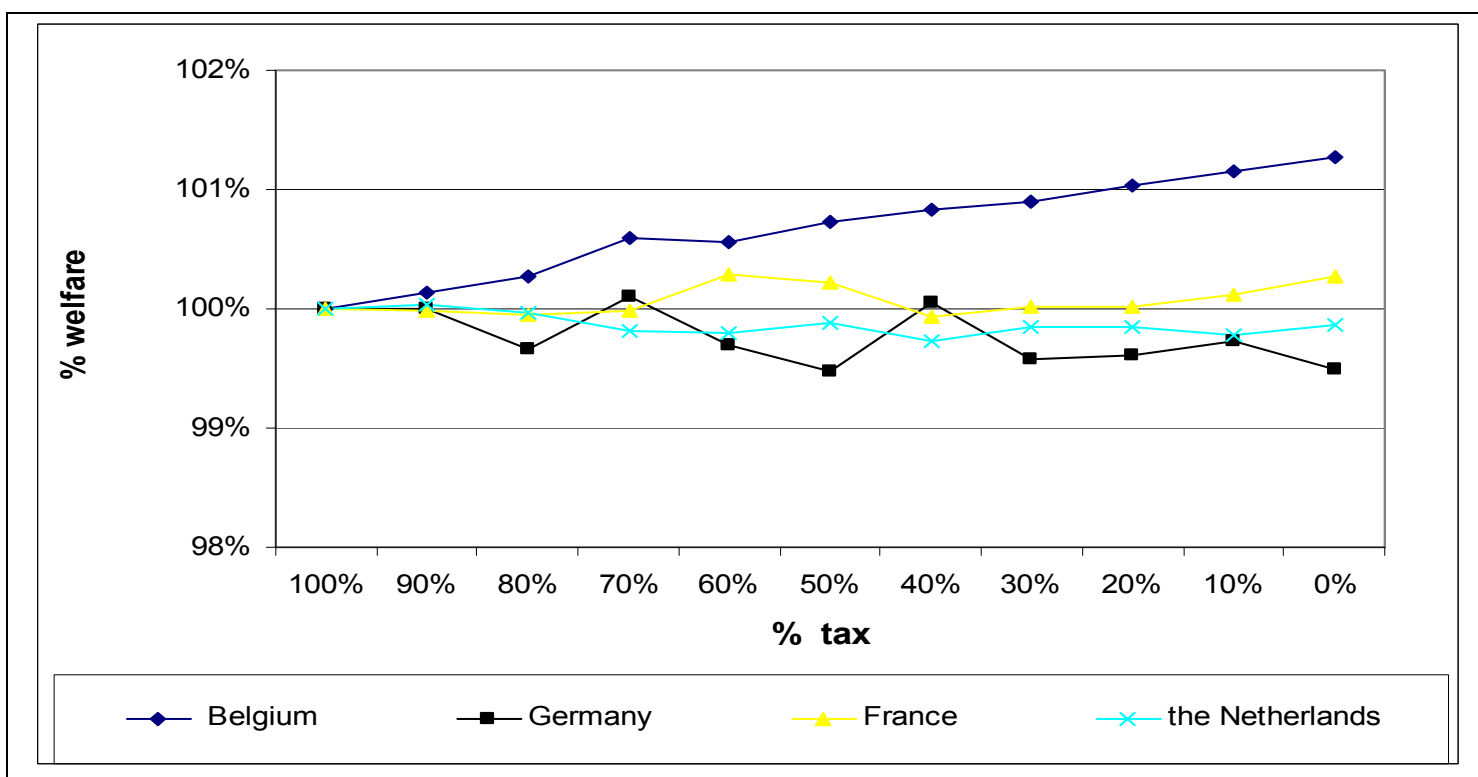

Figure 6b: Welfare effects of unilateral deviations in Belgium from $\mathrm{CO}_{2}$ tax under Cournot competition, only damages from $\mathrm{CO}_{2}$ included in welfare 


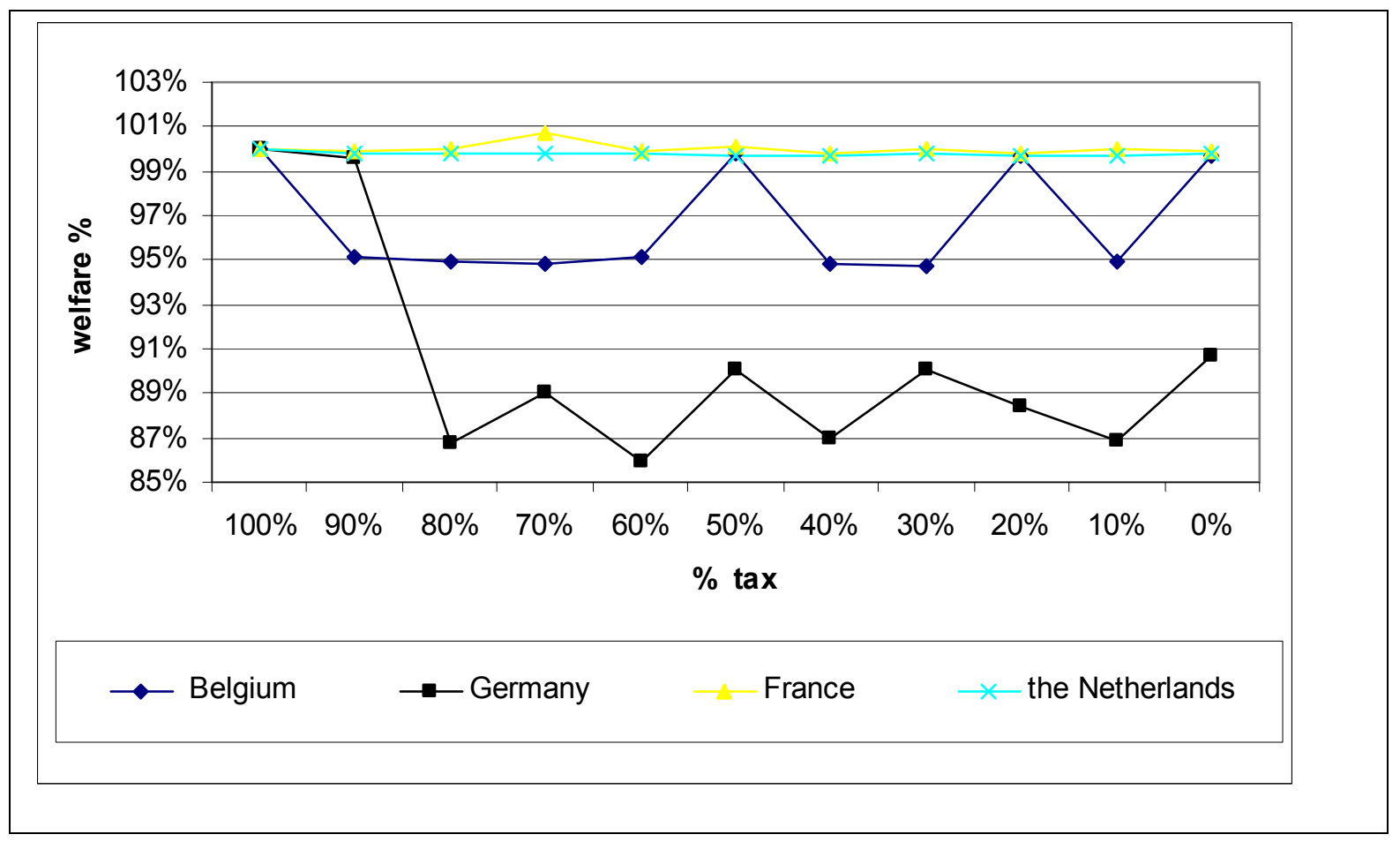

Figure 7a: Welfare effects of unilateral deviations in Germany from $\mathrm{CO}_{2}$ tax under Cournot competition, damages from all pollutants included in welfare

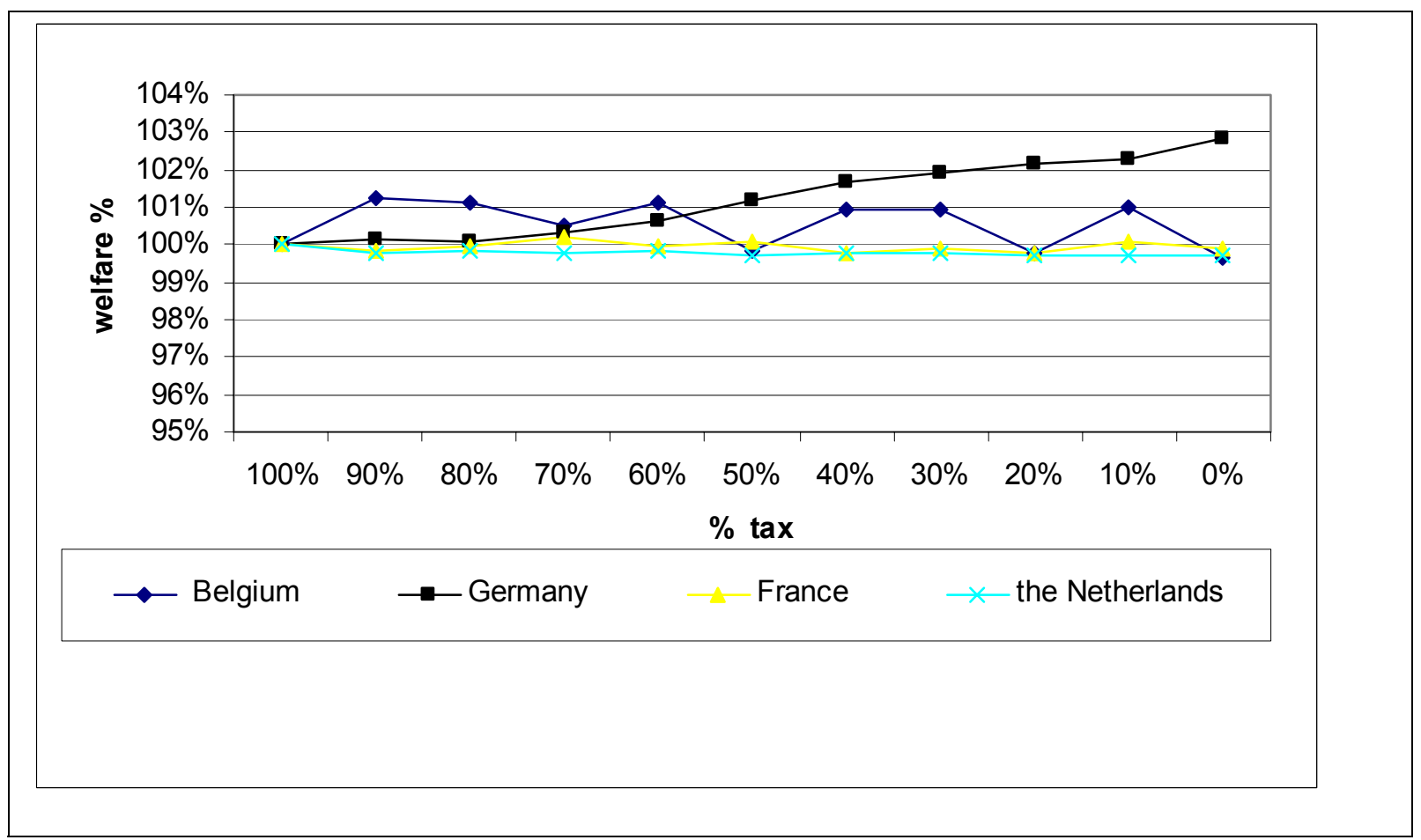

Figure 8b: Welfare effects of unilateral deviations in Germany from $\mathrm{CO}_{2}$ tax under Cournot competition only damages from $\mathrm{CO}_{2}$ included in welfare 
The Opening of the European Electricity Market and Environmental Policy: Does the Degree of Competition Matter?

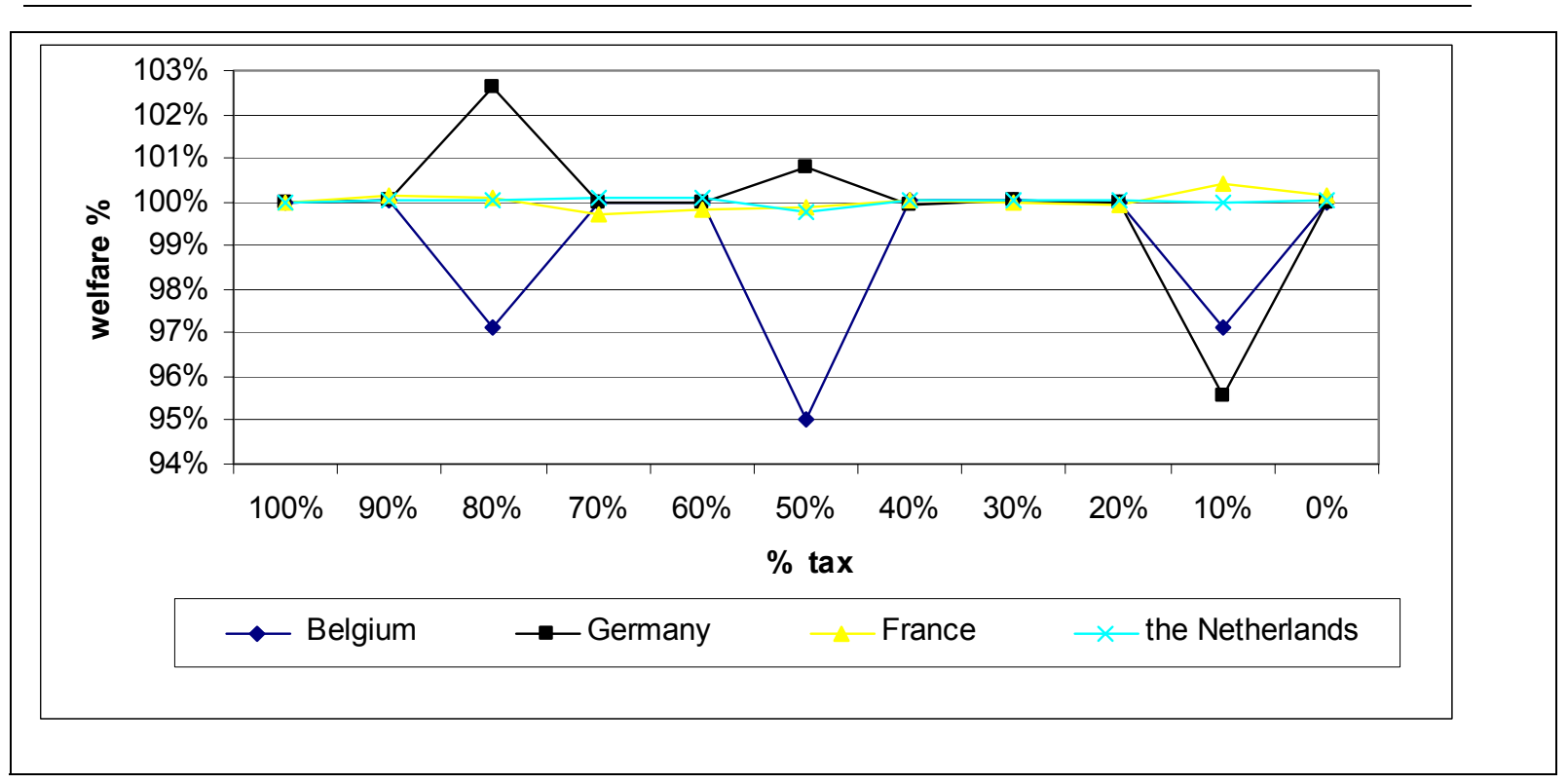

Figure 9a: Welfare effects of unilateral deviations in France from $\mathrm{CO}_{2}$ tax under Cournot competition, damages from all pollutants included in welfare

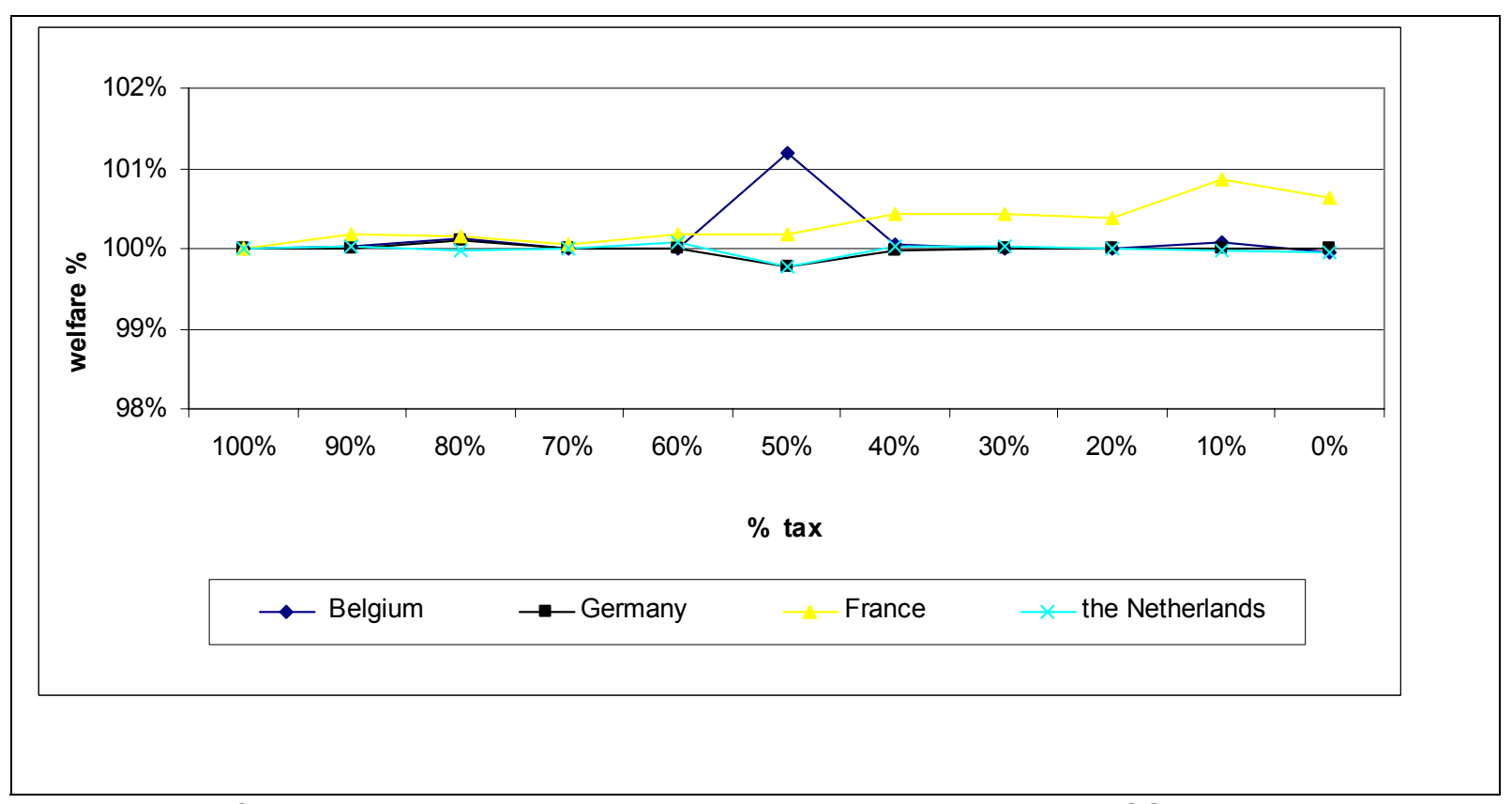

Figure 10b: Welfare effects of unilateral deviations in France from $\mathrm{CO}_{2}$ tax under Cournot competition, only damages from $\mathrm{CO}_{2}$ included in welfare 
The Opening of the European Electricity Market and Environmental Policy: Does the Degree of Competition Matter?

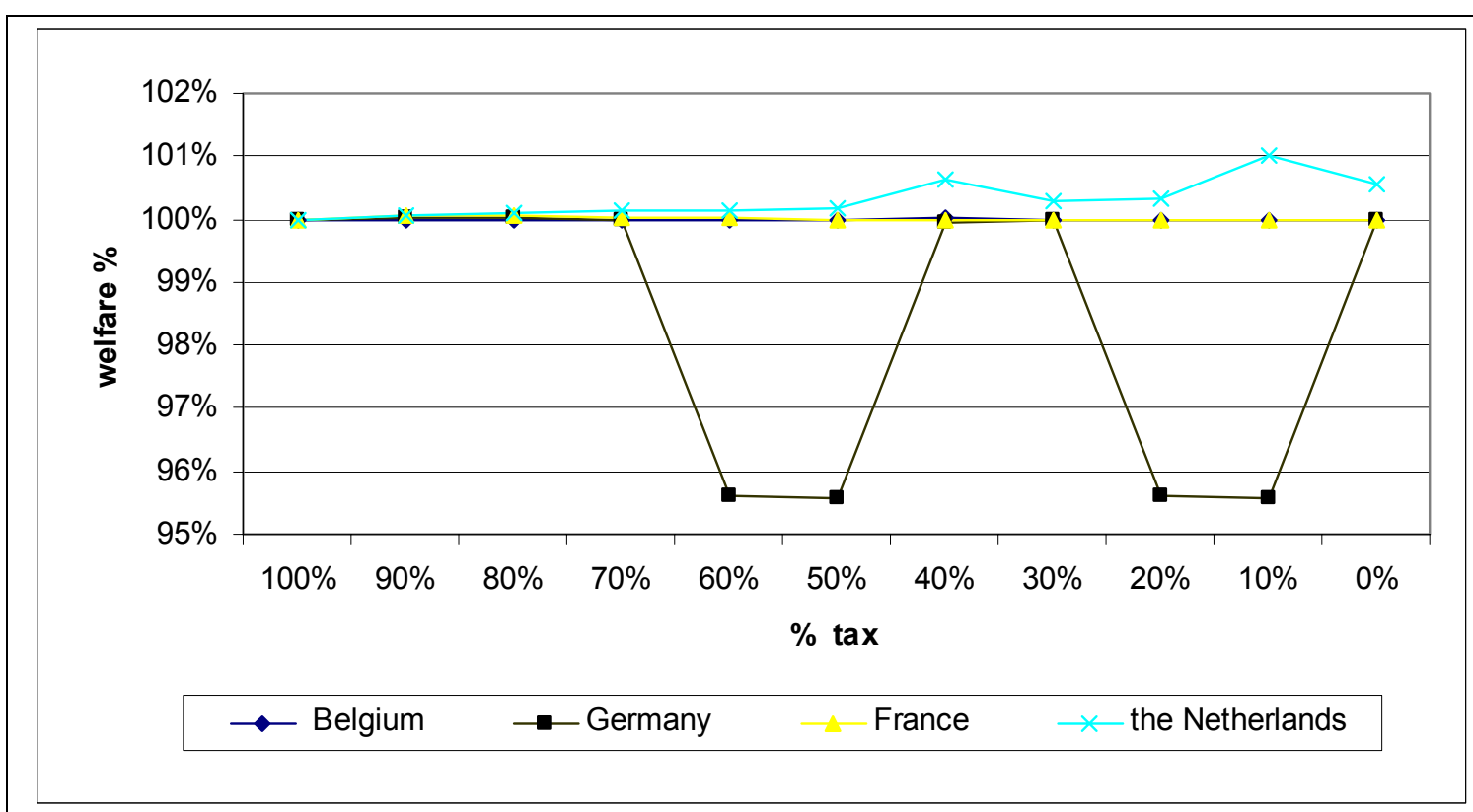

Figure 11a: Welfare effects of unilateral deviations in The Netherlands from $\mathrm{CO}_{2}$ tax under Cournot competition, damages from all pollutants included in welfare

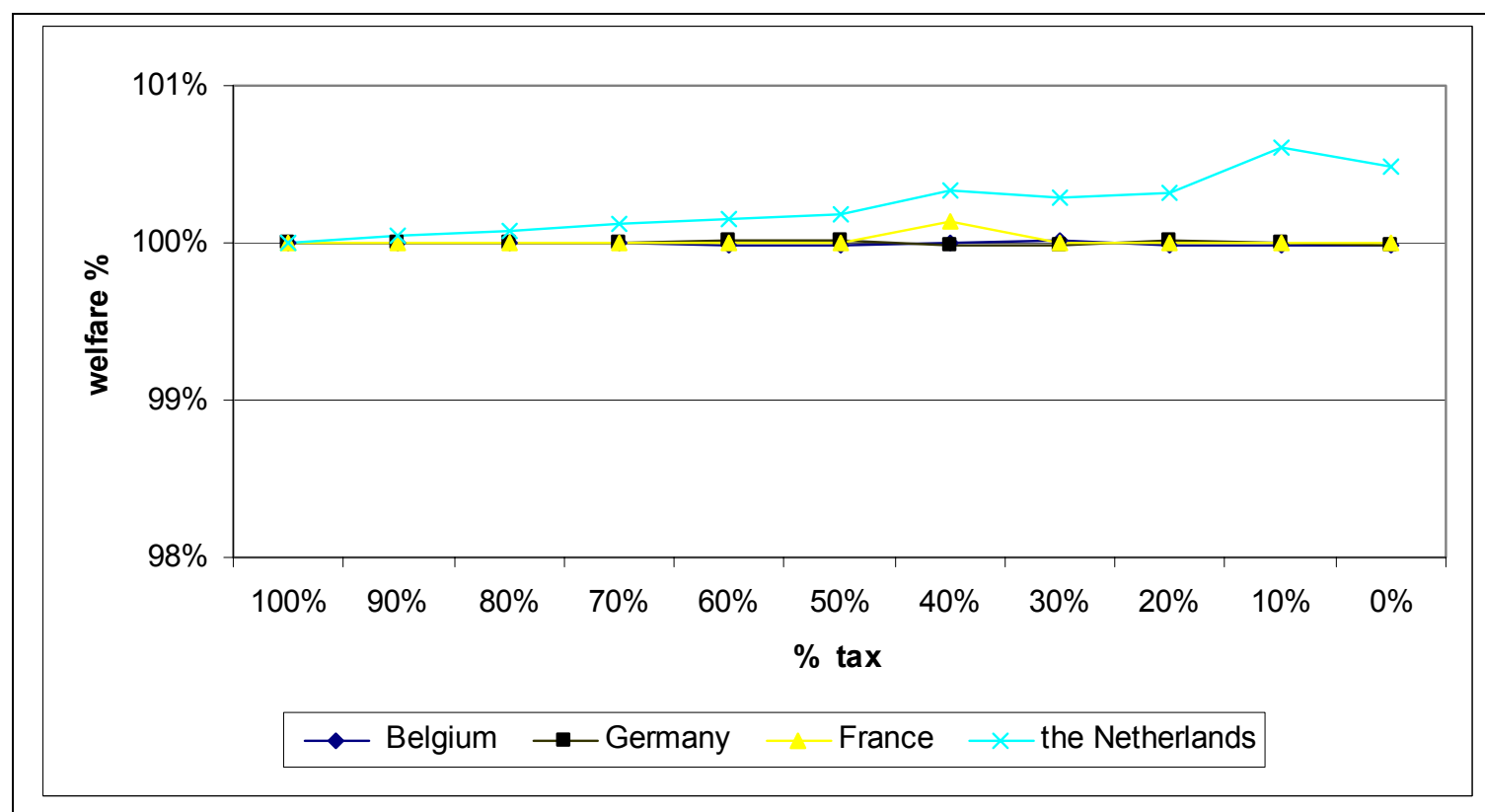

Figure 12b: Welfare effects of unilateral deviations in The Netherlands from $\mathrm{CO}_{2}$ tax under Cournot competition, only damages from $\mathrm{CO}_{2}$ included in welfare 
The Opening of the European Electricity Market and Environmental Policy: Does the Degree of Competition Matter?

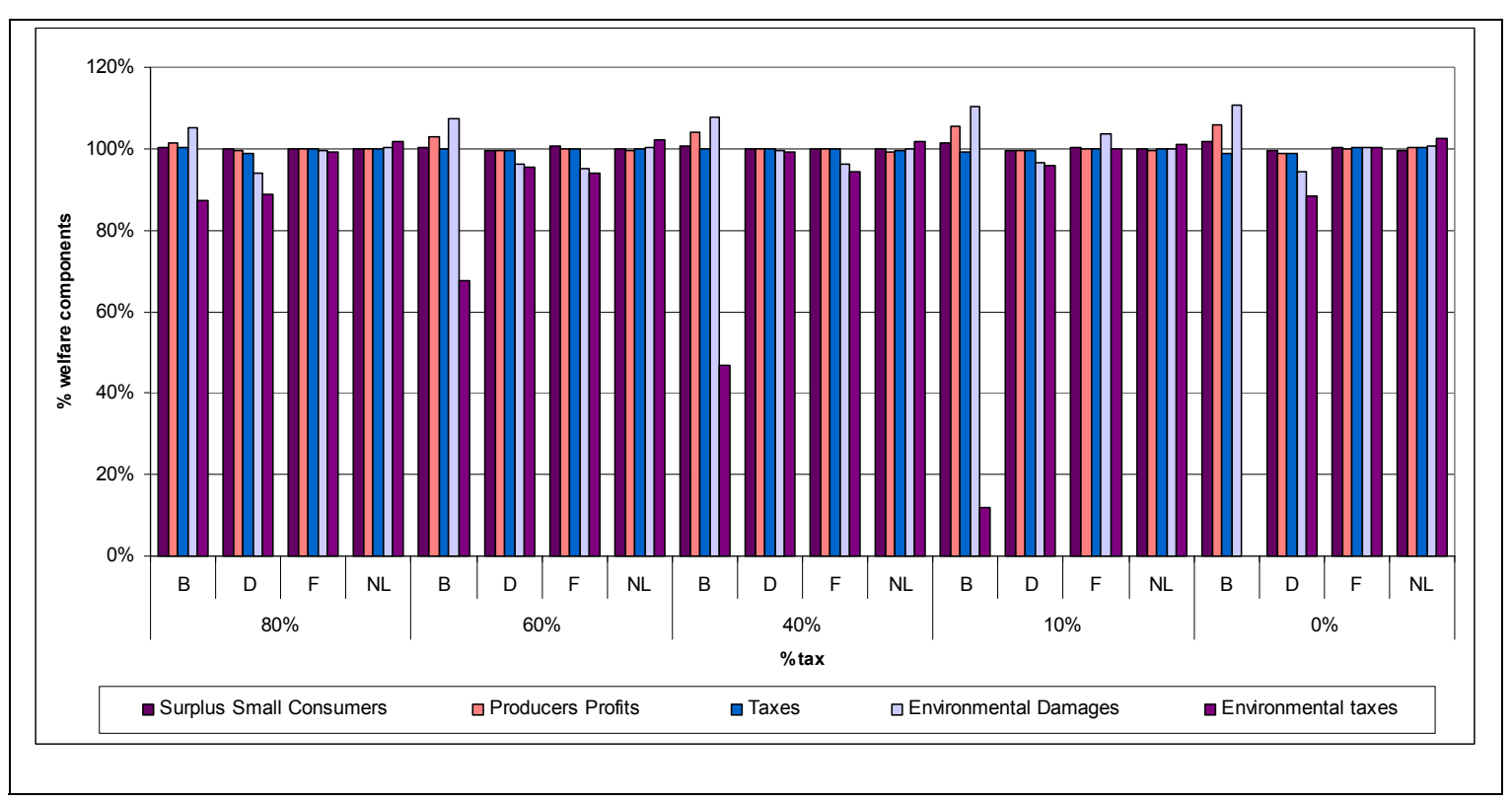

Figure 13: Welfare effects of unilateral deviations in Belgium from $\mathrm{CO}_{2}$ tax under Cournot competition: welfare components in detail

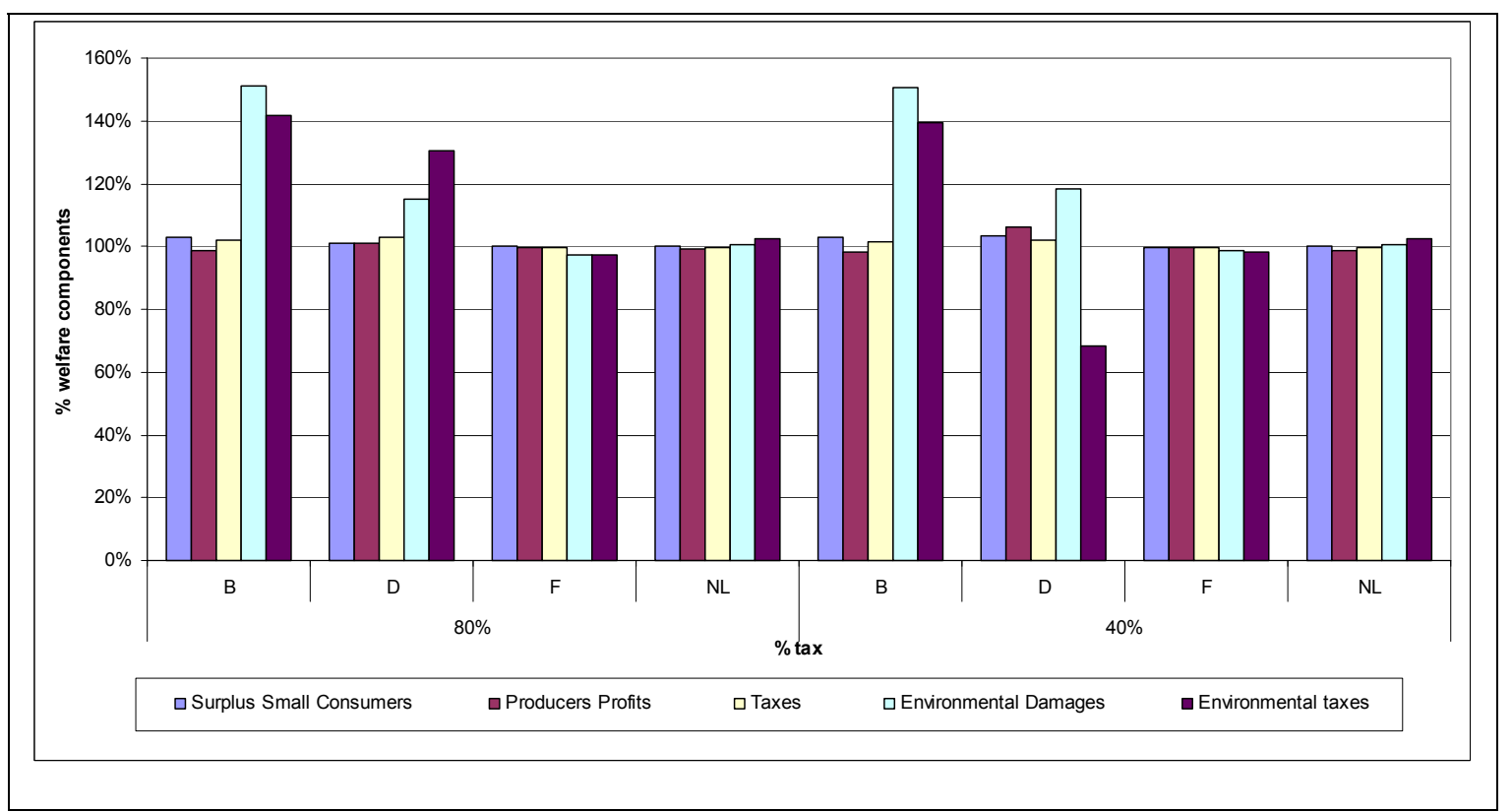

Figure 14: Welfare effects of unilateral deviations in Germany from $\mathrm{CO}_{2}$ tax under Cournot competition: welfare components in detail

Figure $5 \mathrm{a}$ shows the differences between the Cournot outcome under uniform taxes for the four countries and the Cournot equilibria where Belgium unilaterally reduces its $\mathrm{CO}_{2}$ tax by $10 \%$ at the time, while in the other countries the tax is kept constant, when damages from all pollutant are taken into account in the welfare function, while in Figure $5 \mathrm{~b}$ only $\mathrm{CO}_{2}$ damages are taken into account. Figures $6 a, 6 b$ to $8 a, 8 b$ show the same kind of results for Germany, France and The Netherlands. Figures 9 and 10 illustrate the detailed 
effects on welfare components for selected deviations in Belgium and Germany. More detailed tables for the four countries are provided in Appendix B.

Two facts are clear from these results. First, incentives to deviate depend on which environmental damages are included in the welfare function of the governments. Second, some countries may welcome unilateral deviations on the parts of their rival.

As to the first point, notice that if only $\mathrm{CO}_{2}$ damages are taken into account (Figures $5 \mathrm{~b}$, $6 b, 7 b$ and $8 b)$, each of the four countries would welcome any unilateral reduction of its own tax. However, when the damages of all pollutants are included in the welfare function (Figures $5 a, 6 a, 7 a$ and $8 a$ ), only the Netherlands would still find it always profitable to deviate, Germany would never find it profitable, Belgium would welcome a reduction if it is at least $50 \%$, France would consider either small reductions (up to $20 \%$ ) or very large reductions (at least $60 \%$ ). This uneven result is explained by the differences in marginal damages of $\mathrm{SO}_{2}, \mathrm{NO}_{x}$ and TSP emissions across countries, and in the technologies adopted. Germany pollutes more and values the damages from these three pollutants more than the Netherlands. Given the correlation among $\mathrm{CO}_{2}$ and the other atmospheric pollutants, reducing the $\mathrm{CO}_{2}$ tax has harsher consequences in Germany than in the Netherlands. Moreover, the main effect of modifications in the $\mathrm{CO}_{2}$ tax in a country is that either the output levels of operating plants are affected or, for large modifications, the merit order of the plants in that country changes accordingly. This implies that welfare effects of unilateral deviations can be discontinuous, reflecting the switch from less polluting to more polluting plants. This could also explain the non-monotonic pattern of social welfare in Belgium and France. As long as operating plant output is expanded as a response to mild reductions in domestic $\mathrm{CO}_{2}$ taxes, the welfare trade-off is limited to output (and hence domestic surplus) expansion versus increased emissions (and hence, domestic damages) from the same plants. For more substantial reductions, the producer may find it profitable to switch production to dirtier plants with considerably lower operating cost, and the resulting increase in profits and consumers' surplus may well compensate the increase in environmental damages, especially if their marginal value is not too high.

In some instances countries can benefit from unilateral deviations on the part of their rivals. This can happen for two main reasons. Consumers benefit from cheaper imports, and domestic emissions fall as a consequence of the reduction of domestic production. This is Kennedy's (1994) "pollution shifting" effect. In our simulations, this effect is prevailing, for instance, in Belgium as a consequence of unilateral reductions of 10, 30 and $40 \%$ in France's $\mathrm{CO}_{2}$ tax. More often however, fiercer competition from the deviating country reduces welfare in rival countries, both because of the fall in national producers' 
profits, and because the rival producers are forced to adopt dirtier technology to sustain competition, in a sort of a race to the bottom.

An unilateral tax reduction not always induces a fall in the profits of the rival countries (in fact this happens consistently in our simulations only for unilateral deviations in Germany, as shown in Figure 10). Given the discrete nature of technology adoption decisions, and the different transmission capacities of international lines, if a non-deviating country loses market share on a given market as a consequence of a tax reduction in another country, it is not granted that the deviating country would be able to cover it fully. Then some other country could be in a position to satisfy the residual demand, thus expanding its own market share and its profits.

\section{CONCLUSIONS}

In this paper, we used a dynamic numerical model to assess the importance of the degree of competition for the implementation of environmental policies within the European electricity sector.

Our model compares three market regimes: the widely used perfect competition paradigm, a price regulated monopoly regime, and a multi-market Cournot model. The three market regimes have the same electricity transmission constraints. Our environmental policy focus has been on the stringency of environmental policies under imperfect versus perfect competition. Moreover, we examined the effects of unilateral distortions of a $\mathrm{CO}_{2}$ tax.

Our simulations confirm that, even if environmental policy is not optimal, as it is clearly the case for the European electricity sector, perfect competition is clearly superior to Cournot competition when it comes to welfare comparisons. The price regulation regime stands in between the two, but quite close to the perfect competition outcome due to the low profit margin assumed. The higher profits and the lower environmental damages that result from Cournot competition fail to compensate for the huge losses in consumer surplus. In our framework, this result is reinforced by two factors. On the one hand, the limited international transmission capacity leaves significant local market power to generators on their domestic markets. On the other hand, the decrease in output under imperfect competition is sometimes accompanied by a shift towards more polluting technologies, thus reducing the beneficial environmental effects of lower output levels.

As a consequence, our results on the interaction between the market regime and environmental targets are mixed. Whilst the stringency of sulphur dioxide targets declines under Cournot competition, $\mathrm{NO}_{\mathrm{x}}$ targets become more difficult to reach under Cournot competition. As to $\mathrm{CO}_{2}$ taxes, their implementation under Cournot competition leads to 
larger deadweight losses, and hence, the lower emission levels are reached at a higher social cost. Moreover, although overall $\mathrm{CO}_{2}$ emissions are higher under perfect competition, some countries actually experience higher $\mathrm{CO}_{2}$ levels in some years under Cournot competition.

Our investigation on strategic incentives showed that the appeal of unilateral deviations of environmental policy depends crucially on which kind of objective function the governments have and on the environmental policy is pursued for the other pollutants. If they take into account damages from all pollutants and that these pollutants are insufficiently regulated, the attractiveness of unilateral deviations declines sharply compared to the case in which they take only carbon emission damages into account or that the other pollutants are regulated optimally. An interesting and somewhat surprising collateral result is that some governments may welcome unilateral deviations on the part of their opponents. We singled out two factors that may explain this result. On one hand, Kennedy's (1994) "pollution shifting" effect induces governments to welcome to a certain extent electricity imports because of the induced increase in consumers' surplus and decrease in domestic emissions. On the other hand, in presence of transmission constraints and several technologies, a unilateral deviation may cause a rival to lose more market share than the generator based in the deviating country is actually able to cover. Other producers may then jump in and cover the residual demand.

Overall, our simulations suggest that it is worthwhile taking into consideration factors that may lead to preservation of market power, when evaluating environmental policies for the electricity sector

However, our results require a number of qualifications. For one thing, the numerical model in its present form hinges on some strong hypotheses.

In particular the values chosen for transmission costs, transmission capacities, marginal damages of emissions, $\mathrm{CO}_{2}$ tax rate, elasticity of demand, mark-ups on costs in 2000 are all based on educated guesses or, at best, adapted from studies not immune from uncertainties (such as, for instance, ExternE estimates for external damages).

Moreover, some equations of the model are quite rough representations of the real constraints that they are supposed to depict. In particular, international electricity transmission flow equations disregard Kirkhoff's laws, transboundary pollution is included only in the sense that $\mathrm{CO}_{2}$ marginal damages are the same everywhere, but no transboundary matrix for conventional pollutants has been included, and trade to countries other than the four included in the model is not considered, not even as residual trade. Our on-going research is directed to overcome these drawbacks and also to include other 
policy scenarios such as the recent Directive Proposal on renewable energy sources ${ }^{21}$. Our preliminary results indicate that imposing renewable source quotas to European countries can involve serious welfare losses in absence of flexible implementation instruments.

${ }^{21}$ Parliament and Council Directive Proposal No. 500PC0279 (10/05/2000) 


\section{Appendix A : Description of the Numerical Model}

Our model considers the dynamic equilibrium for the electricity sector of four neighbouring European countries: Belgium, the Netherlands, France and Germany. The model is dynamic in the sense that the electricity market equilibrium is modelled for a long time horizon (2000-2034). Such a time span is sufficient to cover the long lifetimes that power production investments generally have, and hence the main differences between nuclear power generation and other technologies can be properly highlighted. Thus, a dynamic setting allows us to take into full consideration the consequences in terms of technology choice of the various policy scenarios we analyse. We assume that all agents have perfect foresight.

Our model consists of:

- A supply module for electricity generation in each country;

- A demand module for electricity in each country;

- An environmental module describing external damages caused by electricity generation in each country;

- A regulatory module describing environmental targets binding for electricity generation in each country;

- A transmission module describing how electricity can be physically exchanged in the international market;

We consider six sub-periods within a year (base, load, medium, shoulder, high, and peak) all having the same length across the four countries. In each country, a single electric utility supplies electricity to the national and international grids using the following technologies:

\begin{tabular}{|ll|ll|}
\hline NP & $\bullet$ Nuclear power plants & KEROP & - Kerosene turbines \\
CP & $\bullet$ Coal power plants & HYP & - Hydro power turbines \\
NCP & - New coal power plants & WP & - Wind turbines \\
MIXP & - Mixed fossil fuel power & WAP & - Municipal waste \\
& plants & incinerators \\
GP & - Gas turbines & CHP & Gas-based co-generation \\
& & & plants \\
NGP & - New gas turbines (STAG) & & \\
\hline
\end{tabular}


Table A.1: Generation technologies

Consumers buy electricity from the municipal distribution company at a price per kWh. This tariff includes marginal costs (production, transport and distribution) and a rent that goes to the municipal distributor. Under perfect competition, the share accruing to producers just covers their marginal costs. Hence, to represent a multi-nodal market equilibrium under perfect competition we use the minimisation of production costs for a given demand. For the algebraic representation of the behaviour of each agent, we will use the following conventions:

\section{SETS}

$t$ years

$v$ vintage year

i sub-periods within a year

$n, m$ nodes (countries: $\mathrm{B}, \mathrm{D}, \mathrm{F}, \mathrm{NL}$ )

$z \quad$ technologies

$E m$ emissions $\left(\mathrm{NO}_{x}, \mathrm{SO}_{2}, \mathrm{CO}_{2}, \mathrm{TSP}\right)$

VARIABLES ${ }^{22}$

$P$ electricity price (Euro/MWh)

$\Pi$ net producer surplus (Euro)

Q consumption (MWh)

$X$ production (MW)

/ investment (MW)

$a b$ electricity transiting through Belgium

Qd electricity transiting through Germany

\section{PARAMETERS}

$\alpha$ distribution of consumption across sub-periods

af availability factor

$\Delta$ lifetime dummy

inv investment cost

$r$ discount factor

dam emission damage (Euro/ton)

$e$ emission rate (ton/MWh)

PARAMETERS (continued)

$t$ emission tax (Euro/ton)

$\theta$ interconnection dummy

$c$ generation cost (Euro/MWh)

lgt length of sub-period (hours)

tra transport cost (Euro/MWh)

$\beta$ weight of Consumers' Surplus

The model is implemented numerically in three stages.

First, a demand function is calibrated for a given demand level. Under perfect competition, producers behave as cost-minimising firms. Since competition sets prices equal to marginal

\footnotetext{
${ }^{22}$ All variables are required to be positive.
} 
costs, for a given demand producers minimise the total costs of electricity supply. We exploit this feature for the calibration of the demand function $P_{n, t}=\left(a_{n, t}-b_{n, t} Q_{n, t}\right)$, where $Q_{n, t}$ is the total quantity sold at $\mathrm{t}$ node $n$ during year $t$. For calibration, demand is exogenously fixed to the observed levels in 2000-2004, and to projected levels in subsequent periods. We have taken into account that what is observed in 2000-2004 is actually the result of price regulation policies by including a price margin per $\mathrm{MWh}$ in that year.

Second, a benchmark perfect competition scenario, with price regulation in 2000 , is computed by means of a welfare maximisation. We use the outcome for 2000 of this reference scenario as the common starting point for all our policy scenarios.

Finally, we compute our policy scenarios. We compare outcomes under perfect competition to outcomes under Cournot competition and price regulation.

A number of constraints further define our problem, and are always present in the three stages described.

Firstly ${ }^{23}$, generated electricity actually supplied at each node, must equal demand at that node.

$(1+$ loss $)\left[\frac{\sum_{i} \alpha_{i, n} Q_{n, t}}{l g t_{i, n}}\right] \leq \sum_{m} \theta_{n, m} \sum_{z} X_{z, i, m, n, t}$

Moreover, each electric producer must take into account capacity constraints for its power plants and reserve constraints for national grids, in order to assure enough supply of electricity even in peak periods.

$$
\begin{aligned}
& \sum_{m} X_{z, i, n, m, t} \leq \sum_{v \leq t} \Delta_{v, t} a f_{n, v} I_{n, z, v} \\
& \left(1+r e s_{n}\right) \frac{\alpha_{P K, n}}{\lg t_{P K, n}} Q_{n, t}<\sum_{v \leq t} \Delta_{v, t} a f_{n, v} I_{n, z, v}
\end{aligned}
$$

Equation (A.2) simply stipulates that output in any given year should never exceed the available capacity, determined by the investments made until that year. Equation (A.3) requires that the same capacity must be sufficient to cover demand in each period plus a reserve margin. Implicitly, it amounts to assuming that each country is in principle selfsufficient, and that trade occurs for comparative efficiency reasons.

${ }^{23}$ In what follows, production $X_{z, i, n, m, t}$ is indexed not only for the period and sub-period in which it is produced, the firm that produces it, the technology used for production, but also for the country where it is generated and the country where it is sent. This allows us to regard the sum of $X_{z, i, n, m, t}$ over $m$ as 
Existent environmental policies are taken into account in terms of unit emissions specifications of the plants and in the form of maximum allowed $\mathrm{NO}_{x}$ and $\mathrm{SO}_{2}$ emissions from Dutch and Belgian plants. The latter are specified in the model by means of the following constraints:

$$
\sum_{m} \sum_{i} \operatorname{lgt} t_{i, n} \sum_{z} e_{e m, z, n, t} X_{z, i, n, m, t} \leq \bar{e}_{e m, n, t} \text { for } n=B, N L \text { and } e m=S O_{2}, N O_{X}
$$

Finally, international electricity sales are constrained by the capacity and the shape of the grid. Since this is rather complex, we will now describe it in detail here.

In order to understand how we model the international transmission of electricity, consider Figure A.1. As shown in the figure, we assume that there are direct interconnections between any couple of countries but the Netherlands and France, and that there are two separate lines connecting any couple of interconnected countries, one for each flow direction. Therefore, electricity traded at any moment between the Netherlands and France must be transmitted using the existing links connecting them with the other two countries, and using the transmission capacity not utilized in that moment for direct trade between countries directly interconnected. For instance, if the French producer sells $X_{i, t} \mathrm{MW}$ to the Dutch market at time $i$ of year $t$, this amount of electricity may reach its destination either passing through Germany or passing through Belgium, but only if at that moment there is enough transmission capacity on the links between France and Germany, Germany and the Netherlands, and/or between France and Belgium, Belgium and the Netherlands. Of course this also influences what can be directly traded between countries that have a direct interconnection. The actual capacity of these lines is then reduced by what is used in order to allow trade between the Netherlands and France.

We take, however, some simplifying assumptions. In particular:

- All transmission lines entail the same transmission cost. This incidentally implies that the transmission cost between France and the Netherlands is double the cost between any two directly interconnected countries;

- Electricity follows the most direct path to any destination. Hence, we rule out the possibility that in order to go from France to the Netherlands (and vice versa), electricity will use the Belgium-Germany line as well.

production per unit of time in country $n$ with technology $z$, and the sum of $X_{z, i, n, m, t}$ over $z$ as sales per unit of time of a firm based in $n$ to country $m$. 


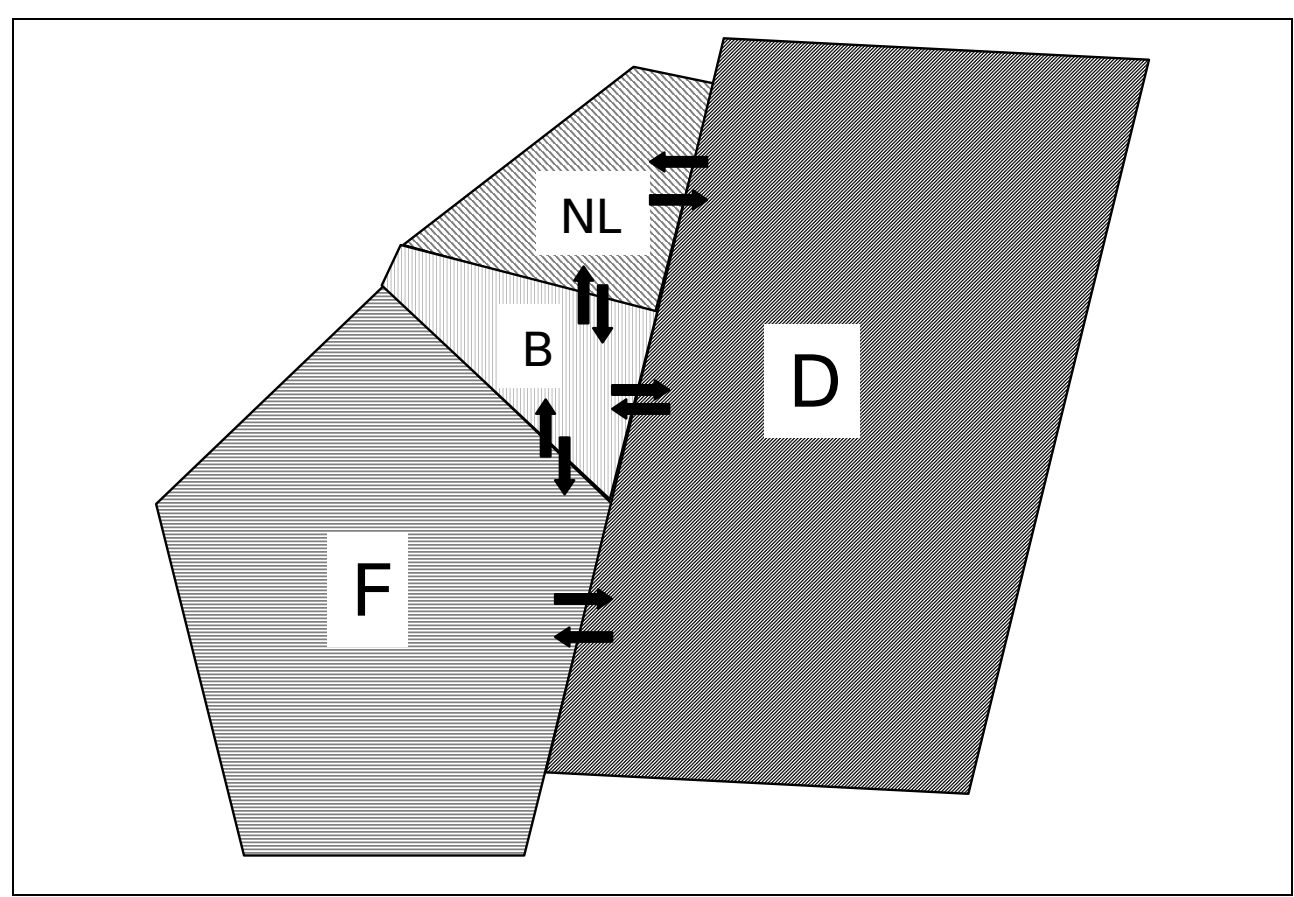

Figure A.1: The international grid

Let $q b_{n, m, i, t}$ be the share of electricity that goes from country $n$ to country $m$ passing through Belgium, and let $q d_{n, m, i, t}$ be the share of electricity that goes from country $n$ to country $m$ passing through Germany. Formally, we then represent the structure of the international grid by means of the following equations.

Electricity sent from France to the Netherlands (and vice versa) goes through either Belgium or Germany:

$\sum_{z} X_{z, i, F, N L, t} \leq q b_{F, N L, i, t}+q d_{F, N L, i, t} ; \sum_{z} X_{z, i, N L, F, t} \leq q b_{N L, F, i, t}+q d_{N L, F, i, t} ;$

Electricity sent from a country to another must not exceed the capacity of the international line, minus the electricity simultaneously transiting through that country and directed either to the Netherlands or France:

$$
\begin{aligned}
& \sum_{z} X_{z, i, B, D, t} \leq Y_{B, D} ; \sum_{z} X_{z, i, D, B, t} \leq Y_{D, B} ; \\
& \sum_{z} X_{z, i, N L, B, t} \leq Y_{N L, B}-q b_{N L, F, i, t} ; \sum_{z} X_{z, i, B, N L, t} \leq Y_{B, N L}-q b_{F, N L, i, t} ; \\
& \sum_{z} X_{z, i, D, F, t} \leq Y_{D, F}-q d_{N L, F, i, t} ; \sum_{z} X_{z, i, F, D, t} \leq Y_{F, D}-q d_{F, N L, i, t} ; \\
& \sum_{z} X_{z, i, N L, D, t} \leq Y_{N L, D}-q d_{N L, F, i, t} ; \sum_{z} X_{z, i, D, N L, t} \leq Y_{D, N L}-q d_{F, N L, i, t} ; \\
& \sum_{z} X_{z, i, D, F, t} \leq Y_{D, F}-q d_{N L, F, i, t} ; \sum_{z} X_{z, i, D, N L, t} \leq Y_{D, N L}-q d_{F, N L, i, t} ;
\end{aligned}
$$




$$
\begin{aligned}
& \sum_{z} X_{z, i, B, N L, t} \leq Y_{B, N L}-q b_{F, N L, i, t} ; \sum_{z} X_{z, i, B, F, t} \leq Y_{B, F}-q b_{N L, F, i, t} ; \\
& \sum_{z} X_{z, i, F, B, t} \leq Y_{F, B}-q b_{F, N L, i, t} ; \sum_{z} X_{z, i, B, F, t} \leq Y_{B, F}-q b_{N L, F, i, t} ;
\end{aligned}
$$

Finally, electricity traded between the two not interconnected countries (France and the Netherlands), must equal the available transmission capacity connecting them to the other two countries minus the electricity otherwise traded using those lines:

$$
\begin{aligned}
& \sum_{z} X_{z, i, N L, F, t} \leq Y_{N L, D}+Y_{N L, B}-\sum_{z} X_{z, i, D, F, t}-\sum_{z} X_{z, i, B, F, t}-\sum_{z} X_{z, i, N L, D, t}-\sum_{z} X_{z, i, N L, B, t} ; \\
& \sum_{z} X_{z, i, F, N L, t} \leq Y_{F, D}+Y_{F, B}-\sum_{z} X_{z, i, F, D, t}-\sum_{z} X_{z, i, F, B, t}-\sum_{z} X_{z, i, D, N L, t}-\sum_{z} X_{z, i, B, N L, t}
\end{aligned}
$$

We can now describe more precisely the three stages of our model.

\section{Cost Minimisation}

The utility's cost minimisation problem is

$$
\begin{aligned}
& \operatorname{Min}_{\substack{X_{z, i, n, m, t} \\
I_{z, n, t}}} C_{n}\left(I_{z, n, t}, X_{z, i, n, m, t}\right)= \\
& \sum_{t} r \sum_{i} \lg t_{i, n}\left[\sum_{z} c_{z, i, n, t} \sum_{m} X_{z, i, n, m, t}+\sum_{m} \theta_{n, m} \operatorname{tra} a_{n, m, t} \sum_{z} X_{z, i, n, m, t}\right]+\sum_{z} \sum_{n}\left[i n v_{z, n, v=t} I_{z, n, v=t}\right]
\end{aligned}
$$

In order to calibrate the demand function, we consider the equilibrium reached when all the costs are minimised, for a given demand:

$$
\operatorname{Min}_{X, 1} \sum_{n}\left(C_{n}\right)
$$

subject to Equations (A.1)-(A.14) and to $Q_{n t}=\bar{Q}_{n t}$.

\section{Perfect Competition Benchmark}

With the parameters of the demand function in hand, we can compute the perfect competition equilibrium. By definition, in such equilibrium the surplus of consumers and producers are maximised, taking prices as given. The perfect competition equilibrium can therefore be mimicked by solving the following problem:

$$
\operatorname{MAX}_{\substack{X_{z, i, n, m, t} \\ I_{n, z, t}}} W=\sum_{n}\left\{\sum_{\mathrm{t}} r\left[C S_{n, t}+\sum_{m} \sum_{i} P_{m, t} \sum_{i} \lg t_{i, n} \sum_{z} X_{z, i, n, m, t}\right]-C_{n}\right\}
$$

subject to Equations (A.1)-(A.14), where

$$
C S_{n, t}=\int_{0}^{Q_{n, t}} P_{n, t}-P_{n, t} Q_{n, t}=a_{n, t} Q_{n, t}-\frac{b_{n, t}}{2} Q_{n, t}^{2}-P_{n, t} Q_{n, t}
$$


is the consumers surplus and where $C_{n}$ is defined in (A.15) .

\section{Policy Scenarios under Perfect and Cournot Competition}

In order to allow comparison among the results of our scenarios, we assume that for all of them the situation in 2000 is the outcome, for that year, of the benchmark model described in the previous Section. We then run our simulations from 2005, keeping fixed the levels of all decision variables in 2000-2004.

Under Perfect Competition, this amounts to solving problem (A.17) from 2005 onwards, subjects to the policy constraints defining each scenario.

Suppose then that firms behave in a non-competitive way in the international electricity market. In any given year $t$, at each node $m$, consumers are prepared to pay for each MWh purchased a price

$$
P_{m, t}\left(X_{z, i, n, m, t}, X_{z, i,-n, m, t}\right)=\left[a_{m, t}-b_{m, t} \sum_{n} \sum_{i} \lg t_{i, n} \sum_{z} X_{z, i, n, m, t}\right]
$$

We assume that producers use open-loop strategies. Each producer's problem then boils down to maximising the discounted stream of his profits taking as given the strategy path of the other producers.

$$
\operatorname{MAX}_{\substack{X_{z, i, n, m, t} \\ \ell_{n, z, t}}} \Pi_{n}=\sum_{t} r\left[\sum_{m} \sum_{i}\left(a_{m, t}-b_{m, t} \boldsymbol{O}_{m, t}\right) \sum_{i} \lg t_{i, n} \sum_{z} X_{z, i, n, m, t}\right]-C_{n}
$$

subject to Equations (A.1)-(A.14) and given $X_{z, i,-n, m, t} X_{, z, i,-n, m, t}, I_{z,-n, t}$ and where $C_{n}$ is defined in (A.15).

Discounted total profits consist of the revenues at each node, minus production and transmission costs.

\section{Welfare Function of the Governments}

In evaluating the outcomes of the various scenarios considered in this paper, we will take the viewpoint of the national governments. Each government will evaluate the consequences of environmental regulations using a Social Welfare function $S W_{n}$. This function encompasses the weighted sum of private surplus of consumers $C S_{n}$ and the producers' surplus $\Pi_{n}$, minus environmental damages $D A M_{n}$ :

$S W_{n}=\beta C S_{n}+\Pi_{n}-D A M_{n}$. 
Total emission damages $D A M_{n}$ take into account emission damages of all pollutants, evaluated using a linear damage function:

$D A M_{n}=\sum_{t} r \sum_{e m, z} \operatorname{dam}_{e m, z, n} \sum_{i} \operatorname{lgt}_{i, n} \sum_{m} X_{z, i, n, m, t} e_{e m, z, n, t}$

The parameter $d_{a m, z, n}$ summarizes the characteristics of emissions of pollutant $e m$ from a plant using technology $z$ in country $n^{24}$.

\footnotetext{
${ }^{24}$ Note that in this formulation, each government cares only about those environmental damages affecting its own territory. The presence of transboundary pollution makes this sub-optimal from an international point of view.
} 


\section{Appendix B : Welfare Effects Of Unilateral Deviations From $\mathrm{CO}_{2}$}

\section{Tax Under Cournot Competition}

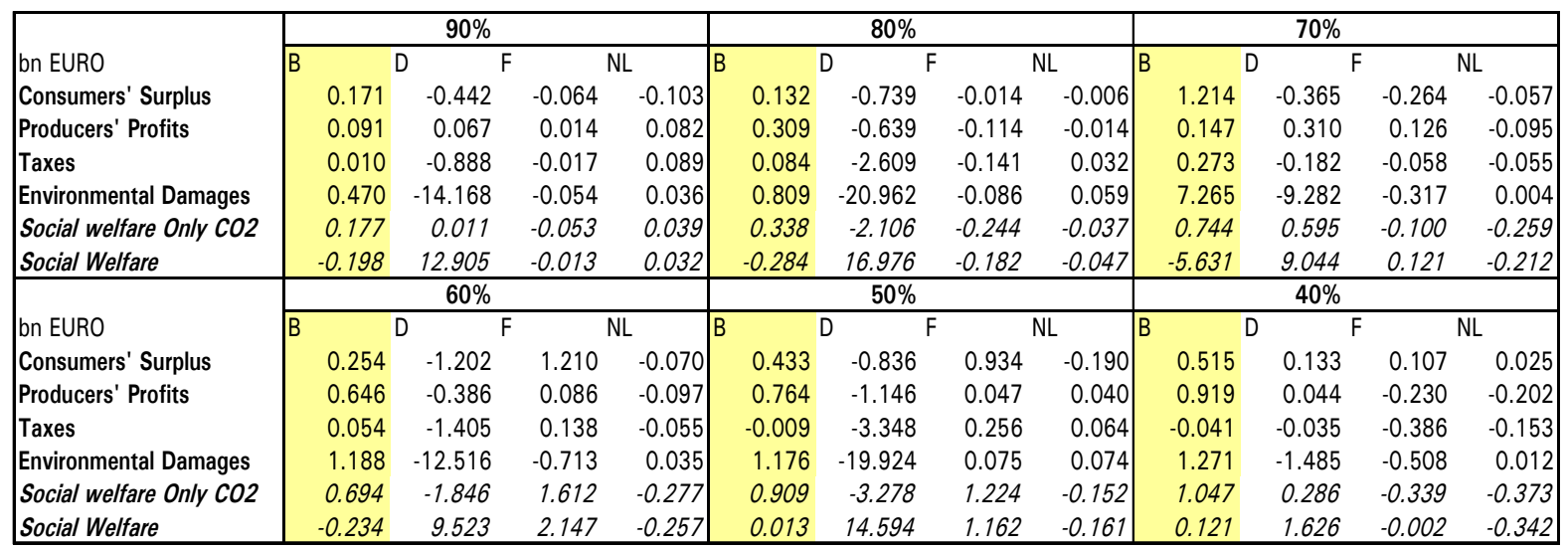

Table Belgium

\begin{tabular}{|c|c|c|c|c|c|c|c|c|c|c|c|c|}
\hline \multirow{3}{*}{$\begin{array}{l}\text { bn EURO } \\
\text { Consumers' Surplus }\end{array}$} & \multicolumn{4}{|c|}{$90 \%$} & \multicolumn{4}{|c|}{$80 \%$} & \multicolumn{4}{|c|}{$70 \%$} \\
\hline & $B$ & $D$ & \multicolumn{2}{|c|}{$\overline{N L}$} & $B$ & $\bar{D}$ & \multicolumn{2}{|c|}{$\overline{N L}$} & $B$ & $\bar{D}$ & \multicolumn{2}{|c|}{$\overline{\mathrm{NL}}$} \\
\hline & 1.895 & 1.087 & -0.413 & -0.037 & 1.760 & 2.672 & 0.226 & 0.133 & 0.959 & 3.010 & 1.200 & 0.099 \\
\hline Producers' Profits & -0.247 & 0.537 & -0.203 & -0.129 & -0.248 & 1.229 & -0.294 & -0.211 & -0.145 & 2.836 & -0.186 & -0.206 \\
\hline Environmental Damages & 8.103 & 2.103 & -0.159 & 0.030 & 8.220 & 51.789 & -0.395 & 0.068 & 7.289 & 44.511 & -4.288 & -0.015 \\
\hline Social welfare Only CO2 & 1.570 & 0.756 & -0.916 & -0.303 & 1.405 & 0.416 & -0.311 & -0.259 & 0.655 & 2.097 & 1.113 & -0.291 \\
\hline Social Welfare & -5.548 & -1.163 & -0.812 & -0.283 & -5.778 & -41.290 & 0.000 & -0.268 & -5.805 & -34.228 & 3.980 & -0.234 \\
\hline \multirow{3}{*}{$\begin{array}{l}\text { bn EURO } \\
\text { Consumers' Surplus }\end{array}$} & \multicolumn{4}{|c|}{$60 \%$} & \multicolumn{4}{|c|}{$50 \%$} & \multicolumn{4}{|c|}{$40 \%$} \\
\hline & \multicolumn{2}{|r|}{$\bar{D}$} & \multicolumn{2}{|c|}{$\mathrm{NL}$} & \multirow{2}{*}{\multicolumn{2}{|c|}{$B \quad D$}} & \multicolumn{2}{|c|}{$\mathrm{NL}$} & \multirow{2}{*}{\multicolumn{2}{|c|}{${ }^{D}$}} & \multicolumn{2}{|c|}{$\mathrm{NL}$} \\
\hline & 1.803 & 5.653 & 0.322 & 0.162 & -0.013 & & 0.821 & 0.035 & 1.781 & & -0.297 & 0.104 \\
\hline Producers' Profits & -0.253 & 3.743 & -0.369 & -0.227 & -0.080 & 5.865 & -0.325 & -0.203 & -0.353 & 7.106 & -0.439 & -0.224 \\
\hline Taxes & 0.887 & 4.944 & -0.334 & -0.133 & -0.084 & 4.594 & -0.150 & -0.159 & 0.775 & 4.311 & -0.562 & -0.143 \\
\hline Environmental Damages & 7.961 & 58.499 & -0.095 & 0.067 & 0.000 & 48.509 & -0.054 & 0.042 & 8.097 & 62.317 & -0.173 & 0.070 \\
\hline Social welfare Only CO2 & 1.445 & 3.727 & -0.348 & -0.258 & -0.177 & 7.414 & 0.360 & -0.364 & 1.219 & 10.228 & -1.247 & -0.322 \\
\hline Social Welfare & -5.524 & -44.160 & -0.287 & -0.265 & -0.178 & -31.111 & 0.400 & -0.370 & -5.894 & -40.794 & -1.125 & -0.332 \\
\hline
\end{tabular}

Table Germany

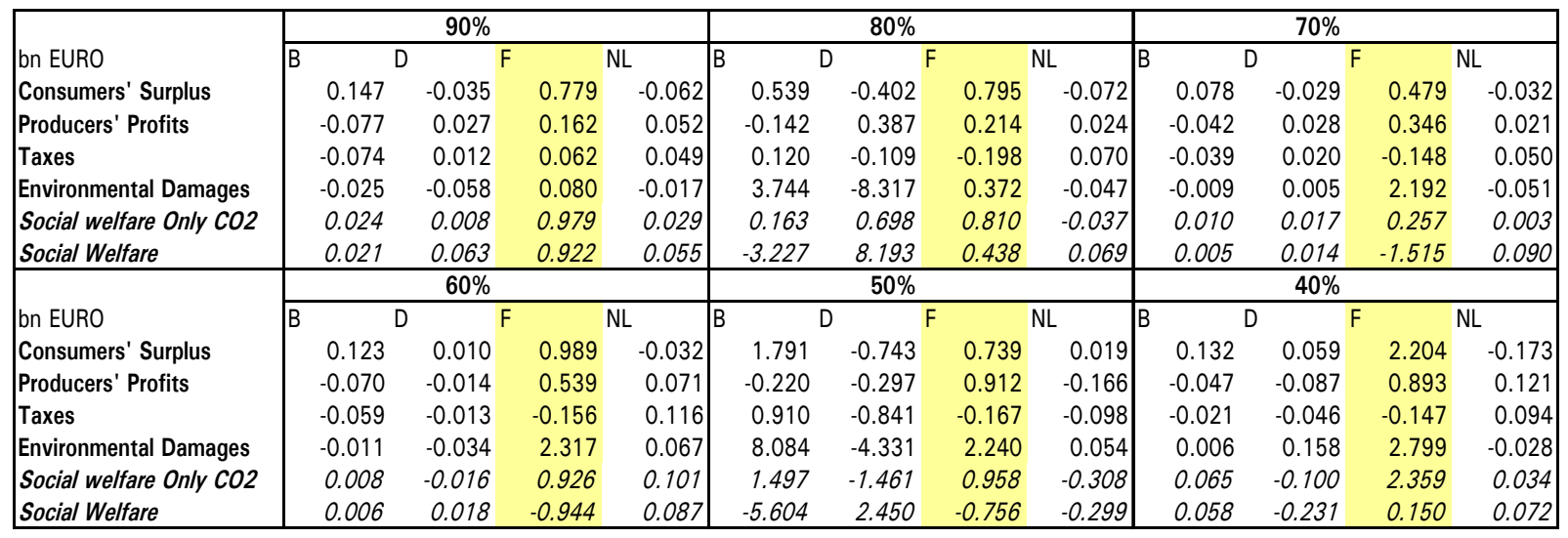

Table France 
The Opening of the European Electricity Market and Environmental Policy: Does the Degree of Competition Matter?

\begin{tabular}{|c|c|c|c|c|c|c|c|c|c|c|c|c|}
\hline \multirow[b]{2}{*}{ bn EURO } & \multicolumn{4}{|c|}{$90 \%$} & \multicolumn{4}{|c|}{$80 \%$} & \multicolumn{4}{|c|}{$70 \%$} \\
\hline & $B$ & $\mathrm{D}$ & \multicolumn{2}{|c|}{$\mathrm{NL}$} & $B$ & $\mathrm{D}$ & \multicolumn{2}{|c|}{$\mathrm{NL}$} & $B$ & $\mathrm{D}$ & \multicolumn{2}{|c|}{$\mathrm{NL}$} \\
\hline Consumers' Surplus & 0.011 & -0.050 & -0.007 & 0.068 & -0.039 & -0.007 & 0.009 & 0.116 & -0.026 & 0.099 & -0.002 & 0.072 \\
\hline Producers' Profits & -0.010 & 0.025 & 0.022 & 0.130 & 0.024 & 0.001 & 0.009 & 0.266 & 0.014 & -0.057 & -0.005 & 0.467 \\
\hline Environmental Damages & -0.011 & -0.029 & -0.342 & 0.040 & -0.024 & -0.054 & -0.359 & 0.113 & 0.007 & 0.020 & -0.070 & 0.131 \\
\hline Social welfare Only CO2 & -0.006 & -0.015 & 0.035 & 0.066 & 0.001 & -0.006 & 0.031 & 0.111 & -0.004 & 0.009 & -0.012 & 0.173 \\
\hline Social Welfare & -0.022 & 0.011 & 0.299 & 0.099 & -0.001 & 0.043 & 0.310 & 0.105 & -0.010 & -0.010 & 0.043 & 0.168 \\
\hline bn EURO & $B$ & $\bar{D}$ & 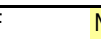 & $\mathrm{L}$ & $B$ & $\bar{D}$ & $\mathrm{~F}$ & $\mathrm{~L}$ & B & $\bar{D}$ & & \\
\hline Consumers' Surplus & -0.020 & 0.237 & -0.015 & 0.100 & 0.025 & 0.220 & -0.006 & 0.143 & 0.016 & 0.108 & 0.762 & 0.303 \\
\hline Producers' Profits & 0.007 & -0.112 & -0.006 & 0.608 & -0.023 & -0.089 & -0.004 & 0.744 & -0.005 & -0.109 & -0.100 & 0.951 \\
\hline Taxes & 0.003 & 1.916 & -0.029 & -0.369 & -0.017 & 1.961 & -0.008 & -0.496 & -0.030 & -0.070 & 0.207 & -0.469 \\
\hline Environmental Damages & 0.000 & 15.736 & -0.081 & 0.159 & 0.007 & 15.916 & -0.004 & 0.176 & -0.025 & 0.049 & 1.054 & -0.019 \\
\hline Social welfare Only CO2 & -0.010 & 0.078 & -0.031 & 0.205 & -0.015 & 0.102 & -0.017 & 0.240 & 0.007 & -0.081 & 0.730 & 0.444 \\
\hline
\end{tabular}

Table the Netherlands 


\section{REFERENCES.}

Barrett, Scott (1994). Strategic Environmental Policy and International Trade. Journal of Public Economics, Vol. 53, n. 3, pp. 325-338.

Bigano, A., Proost, S. and Van Rompuy, J. (2000). Alternative Environmental Regulations Schemes for the Belgian Power Generation Sector. Environmental and Resources Economics. Vol. 16, pp. 121-160.

Böhringer, C, Welsch, H, Löschel, A. (2001), Environmental Taxation and Structural Change in an Open Economy - A CGE Analysis with Imperfect Competition and Free Entry, ZEW Discussion Papers No. 01-07, Mannheim

Burtraw, Dallas, Palmer, Karen, and Heintzelman, Martin (2000). Electricity Restructuring: Consequences and Opportunities for the Environment. Resources for the Future Discussion Paper N. 00-39, Washington D.C.

Brander, J. A. and Spencer, B. J. (1985). Export Subsidies and International Market Share Rivalry. Journal of International Economics Vol. 18, pp. 83-100.

Conrad, Klaus (1993). Taxes and Subsidies for Pollution Intensive Industries as Trade Policy. Journal of Environmental Economics and Management 25, pp. 121-135.

Conrad, K. (1995). Choosing Emission Taxes Under International Price Competition. Fondazione Eni - Enrico Mattei Working Paper 18.95, Milano.

European Commission (1998). Directive on Curbing Emissions from Large Combustion Plants (Proposal). Supplement to Europe Environment, n. 528, $8^{\text {th }}$ September 1998.

European Commission (1999) ExternE: Externalities of Energy, Vol. I-V, European Commission DG XII, Luxembourg.

European Commission (2000) Amended Proposal For a Directive of the European Parliament and of the Council on The Promotion of Electricity from Renewable Sources in the Internal Electricity Market.

Feenstra, Talitha (1998). Environmental Policy Instruments and International Rivalry - $A$ Dynamic Analysis. Ph.D. Dissertation, CentER for Economic Research, Tilburg University, the Netherlands.

Kemfert, Claudia (1999). The Liberalisation Process of the German Electricity Market. Strategies and Opportunities. Fondazione Eni-Enrico Mattei Working Paper n. 95.99 Milano. 
Kennedy, Peter W. (1994). Equilibrium Pollution Taxes in Open Economies with Imperfect Competition. Journal of Environmental Economics and Management, Vol. 27, pp.49-63.

Hobbs, Benjamin (1986). Network Models of Spatial Oligopoly With an Application to Deregulation of Electricity Generation. Journal of Operational Research, Vol 34, pp 395409.

Hogan, William W. (1997) A Market Power Model with Strategic Interaction in Electricity Networks. The Energy Journal, Vol. 18, n. 4, pp. 107-141.

Hoster, Frank, (1997): Effects of National Energy Policies on Carbon Dioxide Emissions in an European Internal Electricity Market: Results From a Simulation Model of the European Power Systems. Fondazione Eni-Enrico Mattei Working Paper 79.97, Milano.

Palmer, Karen, Burtraw, Dallas, Bharvikar Ranijt, and Paul, Anthony (2001). Restructuring and the Cost of Reducing NOx Emissions in Electricity Generation. Resources for the Future Discussion Paper N. 01-10REV, Washington D.C.

Proost, Stef. and Van Regemorter, Denise (2000) How to Achieve Kyoto Targets in Belgium - Modelling Methodology and Some Results. ETE Working Paper Series n. 82000, CES, Katholieke Universiteit Leuven.

Smeers, Yves. (1997): Computable Equilibrium Models and the restructuring of the European Electricity and Gas Market. The Energy Journal. Vol. 18(4), pp:1-31.

Ulph, A. (1996): Environmental Policy And International Trade When Governments And Producers Act Strategically. Journal Of Environmental Economics And Management, Vol. 30, n. 3, pp. 265-281.

Ulph, Alistair (1997): Harmonisation, Minimum Standards, and Optimal International Environmental Policy Under Asymmetric Information. Discussion Paper n. 9701, Department of Economics, University of Southampton.

Ulph, D. (1994) Strategic Innovation And Strategic Environmental Policy. in Carraro, C. (ed) Trade, Innovation, Environment. Kluwer Academic Publishers.

Ulph A. and Ulph, D. (1996) Trade, Strategic Innovation And Strategic Environmental Policy - A General Analysis. in Carraro, C., Katsoulacos, Y. and Xepapadeas, A. (eds) Environmental Policy And Market Structure. Kluwer Academic Publishers, pp. 180-208.

UNIPEDE (1998). Electricity Outlook 1999. Ref. N. 1998-512-0003, UNIPEDE, Brussels. UCTE (2001) Statistical Yearbook 2000. UCTE, Berlin, Germany.

Wei, J-Y and. Smeers, Y. (1997): Spatially Oligopolistic Models With Cournot Producers and Regulated Transportation Prices. C.O.R.E Working Paper n. 9260, Université Catholique de Louvain. 
Welsch, H. (1998). Coal Subsidisation and Nuclear Phase-out in a General Equilibrium Model for Germany. Energy Economics, Vol. 20, pp. 203-222. 
The Center for Economic Studies (CES) is the research division of the Department of Economics of the Katholieke Universiteit Leuven. The CES research department employs some 100 people. The division Energy, Transport \& Environment (ETE) currently consists of about 15 full time researchers. The general aim of ETE is to apply state of the art economic theory to current policy issues at the Flemish, Belgian and European level. An important asset of ETE is its extensive portfolio of numerical partial and general equilibrium models for the assessment of transport, energy and environmental policies.

\section{ETE WORKING PAPER SERIES 2003}

$n^{\circ} 2003-15$

$n^{\circ} 2003-14$

$n^{\circ} 2003-13$

$n^{\circ} 2003-12$

$n^{\circ} 2003-11$

$n^{\circ} 2003-10$

$n^{\circ} 2003-09$

$n^{\circ} 2003-08$

$n^{\circ} 2003-07$

$n^{\circ} 2003-06$

$n^{\circ} 2003-05$

$n^{\circ} 2003-04$

$n^{\circ} 2003-03$
Bigano A., Proost S. (2003), The opening of the European electricity market and environmental policy: does the degree of competition matter?

Pepermans G., Willems B. (2003), Regulating transmission in a spatial oligopoly: a numerical illustration for Belgium

Eyckmans J., Pepermans G. (2003), Is er toekomst voor kernenergie in België?

Franckx L. and D'Amato A. (2003), Environmental policy as a multi-task principal-agent problem

Proost S. And Van Dender K. (2003), Marginal Social Cost Pricing For All Transport Modes And The Effects Of Modal Budget Constraints

Mayeres I., Van Regemorter D. (2003), Modelling the health related benefits of environmental policies - a CGE ANALYSIS for the EU countries with GEM-E3

De Borger B., Proost S., Van Dender K. (2003), Congestion And Tax Competition In A Parallel Network

Pepermans G., Driesen J., Haeseldonckx D., D'haeseleer W. and Belmans R. (2003), Distributed generation: definition, benefits and issues

Moons E., The development and application of economic valuation techniques and their use in environmental policy - A survey

Muys B., Deckmyn G., Moons E., Quijano J.G., Proost S. and Ceulemans R. (2003), An integrated decision support tool for the prediction and evaluation of efficiency, environmental impact and total social cost of forestry projects in the framework of the Kyoto protocol

Proost, S. and Van Regemorter, D. (2003), Climate change policy in European countries and its effects on industry

Willems, B. (2003), Should an incumbent generator be allowed to buy import transmission capacity?

Rousseau, S. and Billiet, C.M. (2003), Using emission standards under incomplete compliance 